\title{
An illustrated key to the soft-bottom caprellids (Crustacea: Amphipoda) of the Iberian Peninsula and remarks to their ecological distribution along the Andalusian coast
}

\author{
José M. Guerra-García • Carlos Navarro-Barranco • \\ Juan Corzo • Vanessa Cobos-Muñoz • Emilio M. García-Adiego • \\ Francisco Sempere Giménez · J. Carlos García-Gómez
}

Received: 29 March 2012/Revised: 17 July 2012/Accepted: 25 July 2012/Published online: 2 September 2012

(C) Springer-Verlag and AWI 2012

\begin{abstract}
The soft-bottom caprellids of the Iberian Peninsula are revised. Nineteen species have been reported so far, $42 \%$ being endemic to the Mediterranean Sea. The lateral view of all of them is provided, together with an illustrated key for all the species. An ecological study was also conducted during 2007-2010 along the Andalusian coast to explore the relationships of caprellids with abiotic data. A total of 90 stations ( $0-40 \mathrm{~m}$ deep) were sampled and 40 contained caprellids. Along the Atlantic, caprellids were present in only $20 \%$ of the stations, while along the Mediterranean coast, caprellids were present in the $75 \%$ of the sampling sites. Furthermore, the abundance of caprellids was also higher in the Mediterranean coast. The dominant species was Pseudolirius kroyeri (present in 24 stations and showing the highest abundances with $1,780 \mathrm{ind} / \mathrm{m}^{2}$ ), followed by Phtisica marina (22 stations) and Pariambus typicus (11 stations). According to CCA and $\mathrm{BIO}-\mathrm{ENV}$, sediment type, $\mathrm{P}, \mathrm{pH}$ and oxygen were the parameters that better explained the distribution of
\end{abstract}

Communicated by H.-D. Franke.

J. M. Guerra-García ( $₫)$ · C. Navarro-Barranco .

J. C. García-Gómez

Laboratorio de Biología Marina, Departamento de Zoología,

Facultad de Biología, Universidad de Sevilla,

Avda Reina Mercedes 6, 41012 Seville, Spain

e-mail: jmguerra@us.es

J. Corzo · V. Cobos-Muñoz · E. M. García-Adiego

Laboratorio de Vigilancia y Control de la Contaminanción,

Agencia de Medio Ambiente y Agua, Palmones,

Calle Trasmallo S/N 11379 Palmones, Los Barrios, Cádiz, Spain

F. S. Giménez

Consejería de Medio Ambiente, Junta de Andalucía,

Avda Manuel Siurot 50, 41013 Seville, Spain caprellids. Although the three dominant species were found in all types of sediment, the univariate approach showed that $P$. kroyeri was significantly more abundant in fine sediments (silt-clay and very fine sands) than in gross sediments (coarse and very coarse sands). The majority of studies dealing with caprellids from the Iberian Peninsula have been focused on shallow waters and further efforts are needed to explore biodiversity of deeper areas.

Keywords Caprellidae $\cdot$ Soft bottoms $\cdot$ Atlantic . Mediterranean - Depth - Sediment type

\section{Introduction}

Caprellids (Crustacea: Amphipoda) are small marine crustaceans which inhabit algae, hydroids, ascidians, anthozoans, bryozoans, sponges, seagrasses and sediments (McCain 1968; Guerra-García 2001). They feed on suspended materials, prey on other organisms or graze on epibiotic fauna and flora (Caine 1974; Guerra-García et al. 2002a; Thiel et al. 2003). In general terms, they can be considered as detritivores (Guerra-García and Tierno de Figueroa 2009). Caprellids are an important prey for many coastal fish species (Caine 1987, 1989, 1991) and have also been found to be useful bioindicators of marine pollution and environmental stress (Guerra-García and García-Gómez 2001; Ohji et al. 2002; Takeuchi et al. 2004; Guerra-García and Koonjul 2005; Guerra-García et al. 2010a).

Although the knowledge of the ecology and taxonomy of amphipod species on the coasts of the Iberian Peninsula has traditionally been considered fragmentary (Jimeno and Turón 1995; Bellan-Santini and Ruffo 1998), an increasing effort has been made during the last decade to understand the biodiversity of caprellids in intertidal and shallow 
waters of Spanish and Portuguese coasts (Guerra-García et al. 2010b), especially in the Strait of Gibraltar. However, most of the studies have been focused on algae (GuerraGarcía et al. 2009, 2010b; Guerra-García and Izquierdo 2010) and the knowledge of the caprellids from soft bottoms is still very scarce. The information available so far is restricted to taxonomical papers including descriptions of new taxa (Guerra-García et al. 2001a, b), inventory of species (de-la-Ossa-Carretero et al. 2010) or community structure of caprellids on seagrasses (González et al. 2008). In spite of the caprellid species Phtisica marina Slabber, 1769 or Pariambus typicus (Krøyer, 1844) are among the dominant taxa in shallow sediment communities of the Iberian Peninsula (Sánchez-Mata 1996; Estacio 1996; Lourido et al. 2008; Sánchez-Moyano and García-Asencio 2010), very little is known about their ecology and distribution.

Consequently, the main aim of the study was to review recent literature in order to provide an illustrated key to all caprellids species reported so far in soft bottoms of the whole Iberian Peninsula. Additionally, an extensive sampling survey was conducted to statistically explore the patterns of ecological preferences (mainly depth and sediment type) and spatial distribution of the dominant species.

\section{Materials and methods}

Fieldwork was carried out along the Andalusian coast (Fig. 1). A total of 90 stations were chosen to encompass the broadest possible range of natural environmental conditions. We selected undisturbed sites with low human impact to avoid the effect of anthropogenic influence on the natural ecological patterns of species. In fact, the selected stations are considered as reference undisturbed monitoring sites for the extensive research programme on sediment communities from the Andalusian coasts (southern Spain) conducted by the Agencia de Medio Ambiente y Agua and supported by the Consejería de Medio Ambiente of the Andalusian Government. This project is in the context of the European Water Framework Directive (WFD) and it is focused on the environmental control of the littoral zone based on the macrofaunal communities and their relationships with the abiotic variables.

As a part of the monitoring programme of the abovementioned project, all the stations were sampled during the summers of 2007, 2009 and 2010. At each station, four replicate samples (three for biological analysis and one for sediment analysis) were taken with a $0.05-\mathrm{m}^{2}$ van Veen grab. Each biological replicate was sieved in seawater through a mesh of $0.5 \mathrm{~mm}$, fixed with $4 \%$ formalin and stained with Bengal rose. All caprellids were sorted and identified to species level. For sediment analysis, organic matter percentage was obtained as weight loss by ignition at $450{ }^{\circ} \mathrm{C}$ for $24 \mathrm{~h}$ and granulometry was assessed following the protocols of Buchanan and Kain (1984). Phosphorous was measured using UV-visible spectrophotometry, and total nitrogen was assessed via Kjeldahl digestion. For water analysis, a water sample per station was obtained close to the bottom by a vertical Alpha Van Dorn-style bottle. Salinity, temperature, $\mathrm{pH}$ and dissolved oxygen were measured with a CTD SBE 10 plus. ClhA was also measured with UV-visible spectrophotometry.

To assess the ecological patterns of the dominant caprellids, univariate and multivariate analyses were conducted. To explore the relationships among abiotic data and the caprellid assemblages, a canonical correspondence analysis (CCA) was applied. The abundance data were transformed with the squared root and the Bray-Curtis similarity index was used. Relationships between multivariate biological structure and environmental data were also examined using the BIO-ENV procedure. Multivariate

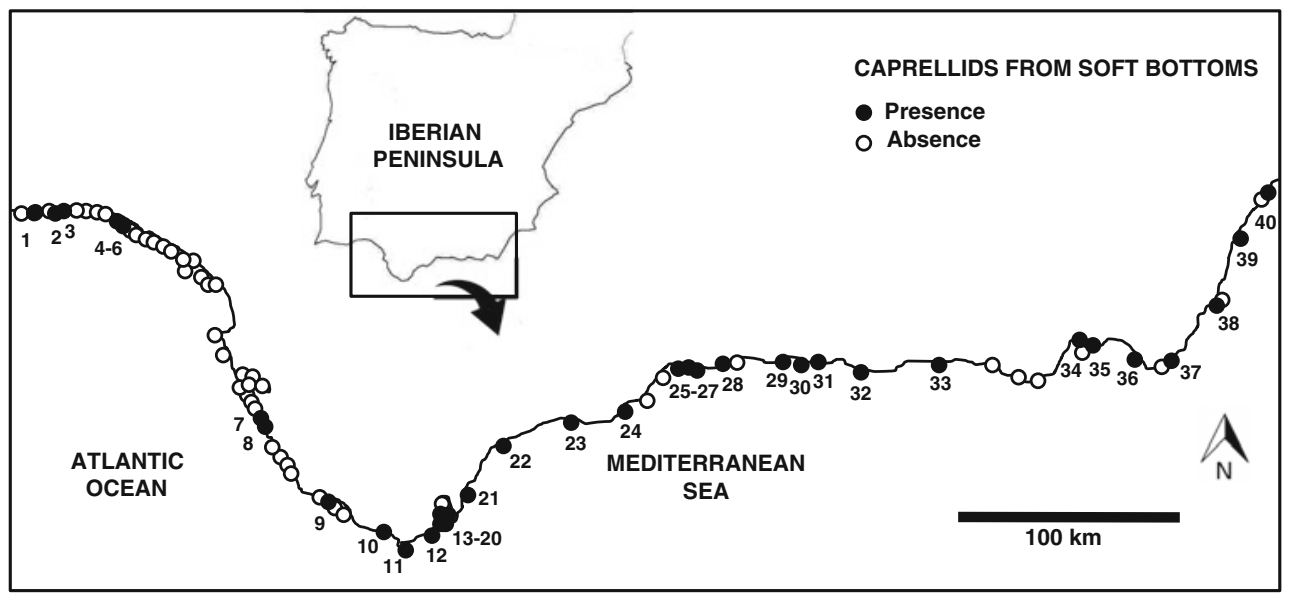

Fig. 1 Study area showing the sampling stations 
analyses were carried out using the PRIMER v.6 package (Clarke and Gorley 2001). To test whether the caprellids' abundance of the main species was similar across depths and sediment types, we used an analysis of variance (ANOVA) with the following factors: 'Depth', a fixed factor, with two levels: 0-15 m and 15-30 m deep; 'Sediment type', a fixed factor and orthogonal, with two levels: gross sediment (gravels and coarse-very coarse sands) and fine sediment (fine-very fine sands and silty and clay); and 'Site', a random factor and nested with 'Sediment type' and 'Depth', with three random sampling sites. From each site, three samples $(n=3)$ of sediment were considered. For this univariate approach, a total of 12 sites were randomly selected of the total 25 stations with caprellids along the Mediterranean coast. Taking into account that in the Atlantic coast there were not enough sites containing caprellids for a balanced statistical design, we only used data of the Mediterranean coast. Prior to ANOVA, heterogeneity of variance was tested with Cochran's $C$ test. Data were transformed with $\ln (x+1)$ if variances were different at $P=0.05$. When variances remained heterogeneous, untransformed data were analysed, as ANOVA is a robust statistical test and is relatively unaffected by heterogeneity of variances, particularly in a balanced design (Underwood 1997). In such cases, special care was taken in the interpretation of results, and to reduce type I errors, the level of significance was reduced to $<0.01$. Univariate analyses were conducted with GMAV5 (Underwood et al. 2002).

\section{Results}

Soft-bottom caprellids from the Iberian Peninsula

Table 1 includes all the species that have been reported so far in soft bottoms of the Iberian Peninsula, including seagrasses and Caulerpa meadows associated with sediments. The following references have been consulted during the review: Mayer (1882, 1890), Cavedini (1981), Krapp-Schickel (1993), Laubitz and Sorbe (1996), Bellan-Santini and Ruffo (1998), Krapp-Schickel and Vader (1998), Estacio (1996), Guerra-García (2001, 2004), Guerra-García et al. (2000, 2001a, b, c, 2002b, 2008, 2010b), Bachelet et al. (2003), González et al. (2008), Lourido et al. (2008), Moreira et al. (2008), Vázquez-Luis et al. (2009), Cacabelos et al. (2010), de-la-Ossa-Carretero et al. (2010), Sánchez-Moyano and García-Asencio (2010, 2011).

Of the 19 species found, 8 species $(42 \%)$ are Mediterranean endemic. Only 2 species, $P$. spinipoda and L. cachuchoensis, can be considered as deep-sea species, although $C$. equilibra, $P$. marina and $P$. phasma have a wide depth range. Caprella caulerpensis, L. cachuchoensis, $P$. major and $P$. spinipoda have been recorded in muddy sediments (silt and clay), whereas C. rapax, C. pseudorapax, C. sabulensis, L. elongatus and $P$. onubensis seem to prefer coarse sands. P. typicus, P. marina, P. kroyeri and $P$. phasma have been found in sediments of different granulometry. Caprella grandimana, $C$. hirsuta, $C$. santosrosai and $D$. schieckei usually inhabit algae instead of sediments; however, they have been also recorded in Caulerpa meadows associated with soft bottoms. Other species, such as $C$. acanthifera, $C$. equilibra, $P$. marina and $P$. phasma, have been found in a variety of other substrates and are not exclusive of sediments.

Figure 2 includes the male lateral view of the 19 species. The following key is based on adult male specimens and it has been elaborated using characters that do not need dissection of mouthparts. Figure 3 provides a generalized caprellid body plan showing the terminology included in this key. Additionally, Fig. 4 graphically compiles the morphological details to be used in conjunction with the provided key.

\begin{tabular}{|c|c|c|}
\hline $1 \mathrm{a}$ & Pereopods 3 and 4 fully articulate & Phtisica marina \\
\hline $\mathrm{b}$ & Pereopods 3 and 4 absent or reduced & 2 \\
\hline $2 \mathrm{a}$ & Head with acute dorsal projection & 3 \\
\hline $\mathrm{b}$ & Head smooth & 4 \\
\hline $3 a$ & $\begin{array}{l}\text { Antenna } 1 \text { longer than half of the body, P3-4 } \\
\text { very reduced. Dorsal projections on head } \\
\text { and pereonites } 1-2\end{array}$ & $\begin{array}{l}\text { Pseudoprotella } \\
\text { phasma }\end{array}$ \\
\hline $\mathrm{b}$ & $\begin{array}{l}\text { Antenna } 1 \text { shorter than half of the body, P3-4 } \\
\text { absent. Dorsal projection on head. } \\
\text { Pereonites 1-2 lacking projections }\end{array}$ & $\begin{array}{l}\text { Caprella } \\
\text { santosrosai }\end{array}$ \\
\hline $4 a$ & $\begin{array}{l}\text { Antenna } 2 \text { very setose. Ventral projection } \\
\text { between gnathopods } 2\end{array}$ & $\begin{array}{l}\text { Caprella } \\
\text { equilibra }\end{array}$ \\
\hline $\mathrm{b}$ & $\begin{array}{l}\text { Antenna } 2 \text { scarcely setose. Ventral projection } \\
\text { among gnathopods } 2 \text { absent }\end{array}$ & 5 \\
\hline $5 a$ & Propodus of gnathopod 2 setose & 6 \\
\hline $\mathrm{b}$ & Propodus of gnathopod 2 not setose & 7 \\
\hline $6 a$ & $\begin{array}{l}\text { Propodus of gnathopod } 2 \text { dorsally with long } \\
\text { setae. Antennae and pereopods with } \\
\text { abundant short setae }\end{array}$ & Caprella hirsuta \\
\hline $\mathrm{b}$ & $\begin{array}{l}\text { Propodus of gnathopod } 2 \text { dorsally with short } \\
\text { setae. Antennae and pereopods with scarce } \\
\text { short setae }\end{array}$ & $\begin{array}{l}\text { Caprella } \\
\text { grandimana }\end{array}$ \\
\hline $7 \mathrm{a}$ & Eyes absent & 8 \\
\hline $\mathrm{b}$ & Eyes present & 9 \\
\hline $8 \mathrm{a}$ & $\begin{array}{l}\text { Triangular projection laterally on the head. } \\
\text { Dorsal projections on the anterior end of } \\
\text { pereonites } 3-5\end{array}$ & $\begin{array}{l}\text { Liropus } \\
\quad \text { cachuchoensis }\end{array}$ \\
\hline $\mathrm{b}$ & Head and pereonites $3-5$ without projections & $\begin{array}{l}\text { Protoaeginella } \\
\text { spinipoda }\end{array}$ \\
\hline $9 \mathrm{a}$ & $\begin{array}{l}\text { Distinct dorsal projections (rounded or acute) } \\
\text { on pereonites } 3-7\end{array}$ & $\begin{array}{l}\text { Caprella } \\
\text { acanthifera }\end{array}$ \\
\hline $\mathrm{b}$ & Dorsal projections absent or tiny & 10 \\
\hline
\end{tabular}




\begin{tabular}{|c|c|c|}
\hline $10 \mathrm{a}$ & $\begin{array}{l}\text { Body very elongate }>8 \mathrm{~mm} \text {. Antennae }>6 \\
\text { times (head }+ \text { pereonite } 1)\end{array}$ & $\begin{array}{l}\text { Parvipalpus } \\
\text { major }\end{array}$ \\
\hline b & $\begin{array}{l}\text { Body }<8 \mathrm{~mm} \text {. Antennae }<6 \text { times } \\
(\text { head }+ \text { pereonite } 1)\end{array}$ & 11 \\
\hline $11 \mathrm{a}$ & Pereopod 5 reduced to 2 articles & 12 \\
\hline $\mathrm{b}$ & Pereopod 5 with 7 articles & 14 \\
\hline $12 \mathrm{a}$ & $\begin{array}{l}\text { Propodus of gnathopod } 2 \text { smooth, without } \\
\text { medial or distal projections. "Abdomen" } \\
\text { with developed pleopods carrying a strong } \\
\text { setae }\end{array}$ & $\begin{array}{l}\text { Pseudolirius } \\
\text { kroyeri }\end{array}$ \\
\hline b & $\begin{array}{l}\text { Propodus of gnathopod } 2 \text { with medial or distal } \\
\text { projection. "Abdomen" without developed } \\
\text { pleopods }\end{array}$ & 13 \\
\hline $13 \mathrm{a}$ & Gnathopod 2 with distal projection & $\begin{array}{l}\text { Liropus } \\
\quad \text { elongatus }\end{array}$ \\
\hline $\mathrm{b}$ & Gnathopod 2 with medial projection & $\begin{array}{l}\text { Pariambus } \\
\text { typicus }\end{array}$ \\
\hline $14 \mathrm{a}$ & $\begin{array}{l}\text { Pereopods } 3 \text { and } 4 \text { present, reduced to } \\
\text { 2-articles }\end{array}$ & $\begin{array}{l}\text { Deutella } \\
\text { schieckei }\end{array}$ \\
\hline $\mathrm{b}$ & Pereopods 3 and 4 absent & 15 \\
\hline $15 \mathrm{a}$ & Head with a short rostrum & $\begin{array}{c}\text { Parvipalpus } \\
\text { onubensis }\end{array}$ \\
\hline $\mathrm{b}$ & Head without rostrum & 16 \\
\hline $16 \mathrm{a}$ & Suture between head and pereonite 1 present & 17 \\
\hline $\mathrm{b}$ & Suture absent & 18 \\
\hline $17 \mathrm{a}$ & Head 'skull' like & $\begin{array}{l}\text { Caprella } \\
\text { caulerpensis }\end{array}$ \\
\hline b & Head smooth and rounded & $\begin{array}{l}\text { Caprella } \\
\text { sabulensis }\end{array}$ \\
\hline $18 \mathrm{a}$ & Eyes reduced to $6-8$ ocelles & $\begin{array}{l}\text { Caprella } \\
\text { pseudorapax }\end{array}$ \\
\hline b & Eyes normal & $\begin{array}{l}\text { Caprella } \\
\text { rapax }\end{array}$ \\
\hline
\end{tabular}

Sampling survey along Andalusian coast

\section{Caprellid assemblages}

Of the 90 stations sampled along the coast, 40 contained caprellids (Table 2; Fig. 1). Along the Atlantic shore, caprellids were present only in $20 \%$ of the stations, while along the Mediterranean coast, caprellids were present in $75 \%$ of the sampling sites. Furthermore, the abundance of caprellids was also higher in the Mediterranean coast (Fig. 5). Seven species were identified from the samples: Caprella acanthifera Leach, 1814, Caprella rapax Mayer, 1890, Caprella sabulensis Guerra-García, SánchezMoyano and García-Gómez, 2001, Pseudolirius kroyeri (Haller, 1879), P. marina Slabber, 1769, Pseudoprotella phasma (Montagu, 1804) and P. typicus Krøyer, 1844 (Table 2). The dominant species was $P$. kroyeri (present in 24 stations and showing the highest abundances), followed by $P$. marina (22 stations) and P. typicus (11 stations). The remaining 4 species were occasional: $C$. acanthifera was only present in stations 30 and $40, C$. rapax only in station 9, C. sabulensis in station 2 and 11, and P. phasma in stations 5 and 9 . The highest abundance was measured for P. kroyeri with a mean value of $1,780 \mathrm{ind} / \mathrm{m}^{2}$.

\section{Abiotic data}

Water depth at the stations ranged from 3 to $36 \mathrm{~m}$ (Table 2). A variety of sediment types was represented, with stations dominated by gravels (e.g. station 1 or 11), coarse and very coarse sands (e.g. stations 9, 12, 23, 30, 31, 33 or 35 ), medium sands (e.g. stations 28 or 36 ), fine and very fine sands (most of the stations) and silt and clay (e.g. stations $4,5,13,17,18,20,25,26,31,32$ or 34$)$. The organic matter content was low in most of the stations; however, values higher than $6 \%$ were measured in some stations of the Atlantic coast (Huelva and Cádiz) coinciding with the discharges of the main rivers. High $\mathrm{P}$ and $\mathrm{N}$ concentrations were also measured in stations of the Atlantic coast, but also in the Mediterranean site of Algeciras Bay (e.g. station 20). Regarding water samples, ClhA ranged from 0.10 to $4.73 \mathrm{mg} / \mathrm{m}^{3}$, oxygen from 4.0 to $8.1 \mathrm{mg} / \mathrm{l}$, salinity from 35.31 to $40.54 \mathrm{psu}$, temperature from 14.5 to $26.7^{\circ} \mathrm{C}$ and $\mathrm{pH}$ from 7.54 to 8.40 .

\section{Multivariate approach}

According with the results of the Table 2, the three dominant caprellids, P. kroyeri, P. marina and P. typicus, were present in a variety of depths and sediment types, showing that the three species are able to live in gravels, coarse sands, medium sands, fine sands or silt and clays. The BIO-ENV analysis produced the best correlation (0.21) for the combination of the variables Chla, oxygen, salinity, $\mathrm{pH}, \mathrm{P}$ and medium sands, but this correlation was very low. However, when the exploratory multivariate approach was conducted throughout the CCA, higher correlations were obtained (Fig. 6; Table 3). The first axis explained the $28.4 \%$ of the total variance and correlated mainly with granulometry and $\mathrm{pH}$. While $P$. kroyeri was mainly related with the percentage of the finest fractions (silts and clays) and higher values of $\mathrm{pH}, P$. typicus and $P$. marina were associated with the gross fractions (gravels, coarse and medium sands) and lower values of $\mathrm{pH}$. The second axis correlated with oxygen measured in the water column (bottom) and P measured in sediments. These two variables separated the species $P$. typicus from $P$. marina, being the first associated with more oxygenated stations, while the latter is able to live in stations with higher contents of phosphorous and lower oxygen concentrations. 
Table 1 Caprellids collected from soft bottoms of the Iberian Peninsula

\begin{tabular}{|c|c|c|c|c|}
\hline Name of species & Distribution & Depth (m) & Type of sediments & Other substrates \\
\hline Caprella acanthifera Leach, 1814 & $\mathrm{M}, \mathrm{A}$ & $0-90$ & MS-CS, $\mathrm{Cn}, \mathrm{Po}, \mathrm{Zm}$ & $\mathrm{Al}, \mathrm{Hy}, \mathrm{As}, \mathrm{An}, \mathrm{Sp}, \mathrm{Br}$ \\
\hline $\begin{array}{l}\text { Caprella caulerpensis Guerra-García, } \\
\text { Sánchez-Moyano and García-Gomez, } 2002\end{array}$ & $\mathrm{E}$ & 5 & SC with $C p$, high $\mathrm{OM}(>10 \%)$ & \\
\hline Caprella equilibra Say, 1818 & $\mathrm{M}, \mathrm{A}, \mathrm{P}, \mathrm{I}$ & $0-3,000$ & Sandy bottoms with $C n$ & $\mathrm{Al}, \mathrm{Hy}, \mathrm{As}, \mathrm{Sp}, \mathrm{Br}$ \\
\hline Caprella grandimana Mayer, 1882 & $\mathrm{E}$ & $0-10$ & Sediments with $\mathrm{Cr}$ & $\mathrm{Al}$ \\
\hline Caprella hirsuta Mayer, 1890 & $\mathrm{E}$ & $0-40$ & Sediments with $\mathrm{Cr}$ & $\mathrm{Al}, \mathrm{Hy}, \mathrm{Eq}$ \\
\hline $\begin{array}{l}\text { Caprella pseudorapax Guerra-García, } \\
\text { Sánchez-Moyano and García-Gómez, } 2001\end{array}$ & $\mathrm{E}$ & $20-30$ & MS-CS, low OM $(<1 \%)$ & \\
\hline Caprella rapax Mayer, 1890 & $\mathrm{M}, \mathrm{A}$ & $1-80$ & $\mathrm{CS}, \mathrm{Po}$ & \\
\hline $\begin{array}{l}\text { Caprella sabulensis Guerra-García, Sánchez- } \\
\text { Moyano and García-Gómez, } 2001\end{array}$ & $\mathrm{M}, \mathrm{A}$ & $20-30$ & MS-CS, biodetritic, low OM (<1 \%) & \\
\hline $\begin{array}{l}\text { Caprella santosrosai Sánchez-Moyano, } \\
\text { Jiménez-Martín and García-Gómez, } 1995\end{array}$ & $\mathrm{E}$ & $0-40$ & Sediments with $\mathrm{Cr}$ & Al, Hy, An, Sp \\
\hline Deutella schieckei Cavedini, 1982 & $\mathrm{E}$ & $0-10$ & Sediments with $C p$ and $C r$ & $\mathrm{Al}$ \\
\hline $\begin{array}{l}\text { Liropus cachuchoensis Guerra-García, Sorbe } \\
\text { and Frutos, } 2008\end{array}$ & A & $619-1,062$ & $\mathrm{SC}$ with medium OM (4-6\%) & \\
\hline Liropus elongatus Mayer, 1890 & $\mathrm{E}$ & $25-30$ & Sandy bottoms, $P o, P e$ & \\
\hline Pariambus typicus Krøyer, 1844 & $\mathrm{M}, \mathrm{A}$ & $0-40$ & G, CS, MS, FS, SC, $C n, Z m, Z n$ & $\mathrm{Eq}$ \\
\hline Parvipalpus major A. Carausu, 1941 & $\mathrm{M}, \mathrm{A}$ & $0-924$ & Muddy sands to mud, $P o$ & $\mathrm{Al}$ \\
\hline $\begin{array}{l}\text { Parvipalpus onubensis Guerra-García, } \\
\text { García-Asencio and Sánchez-Moyano, } \\
2001\end{array}$ & A & 20 & CS, low OM $(<2 \%)$ & \\
\hline Phtisica marina Slabber, 1769 & $\mathrm{M}, \mathrm{A}, \mathrm{P}$ & $0-660$ & $\mathrm{G}, \mathrm{CS}, \mathrm{MS}, \mathrm{FS}, \mathrm{SC}, \mathrm{Cn}, \mathrm{Po}, \mathrm{Zm}, \mathrm{Zn}$ & $\mathrm{Al}, \mathrm{Hy}, \mathrm{As}, \mathrm{An}, \mathrm{Sp}, \mathrm{Br}, \mathrm{Eq}$ \\
\hline $\begin{array}{l}\text { Protoaeginella spinipoda Laubitz and Sorbe, } \\
1996\end{array}$ & A & $2,990-3,070$ & $\mathrm{SC}$ & \\
\hline Pseudolirius kroyerii (Haller, 1879) & $\mathrm{E}$ & $0-62$ & $\mathrm{G}, \mathrm{CS}, \mathrm{MS}, \mathrm{FS}, \mathrm{SC}$ & \\
\hline Pseudoprotella phasma (Montagu, 1804) & $\mathrm{M}, \mathrm{A}$ & $0-2,450$ & G, CS, MS, FS, SC, Cn, Po, Zm, Zn & Al, Hy, An \\
\hline
\end{tabular}

Species collected from seagrasses and Caulerpa spp. growing on sediments are also included

References: Mayer (1882, 1890), Cavedini (1981), Krapp-Schickel (1993), Laubitz and Sorbe (1996), Bellan-Santini and Ruffo (1998), KrappSchickel and Vader (1998), Estacio (1996), Guerra-García (2001, 2004), Guerra-García et al. (2000, 2001a, b, c, 2002b, 2008, 2010b), Bachelet et al. (2003), González et al. (2008), Lourido et al. (2008), Moreira et al. (2008), Vázquez-Luis et al. (2009), Cacabelos et al. (2010), de-la-OssaCarretero et al. (2010), Sánchez-Moyano and García-Asencio (2010, 2011)

$E$ Mediterranean endemic, $M$ Mediterranean Sea; $A$ Atlantic ocean; $P$ Pacific Ocean; $I$ Indian Ocean. $C S$ coarse sand; $M S$ medium sand; $F S$ fine sand; SC silt and clay; OM organic matter; Cn Cymodocea nodosa; Po Posidonia oceanica; Zm Zostera marina; Zn Zostera noltii; C Caulerpa; Cp Caulerpa prolifera; Cr Caulerpa racemosa; Pe Peysonnelia; Al algae; Hy hydroids; As ascidians; An, antozoans; $S p$, sponges; $B r$ bryozoans; Eq equinoderms

\section{Univariate design}

To verify the influence of sediment type on the abundance of the dominant caprellid species (P. kroyeri, P. marina and $P$. typicus), a three-way ANOVA was conducted, including not only the sediment's granulometry, but also water depth as a factor. The abundance of each species was similar in shallow $(0-15 \mathrm{~m})$ and deep $(15-30 \mathrm{~m})$ stations (Table 4; Fig. 7). On the other hand, ANOVA results evidenced no significant differences in the abundances of $P$. marina and P. typicus between gross (gravels and coarse-very coarse sands) and fine sediments (fine-very fine sands and silts and clays), although $P$. kroyeri showed higher abundances in fine sediments (Table 4; Fig. 7), in spite of the differences among sites.

\section{Discussion}

Ecological remarks of soft-bottom caprellids

The present study reveals that the dominant caprellid species from shallow soft bottoms of southern Spain (P. kroyeri, P. typicus and P. marina) may inhabit different sediment types, from gravels to silts and clays. However, univariate analyses confirmed that $P$. kroyeri was significantly more abundant in fine-very fine sands and muddy sediments than coarse sands and gravels. This is in agreement with Krapp-Schickel (1993) who described the species as typical from muddy bottoms, sometimes commensal with pelagic Salpa mucronata. In spite of the high abundance of $P$. kroyeri shown by this study, the species has 

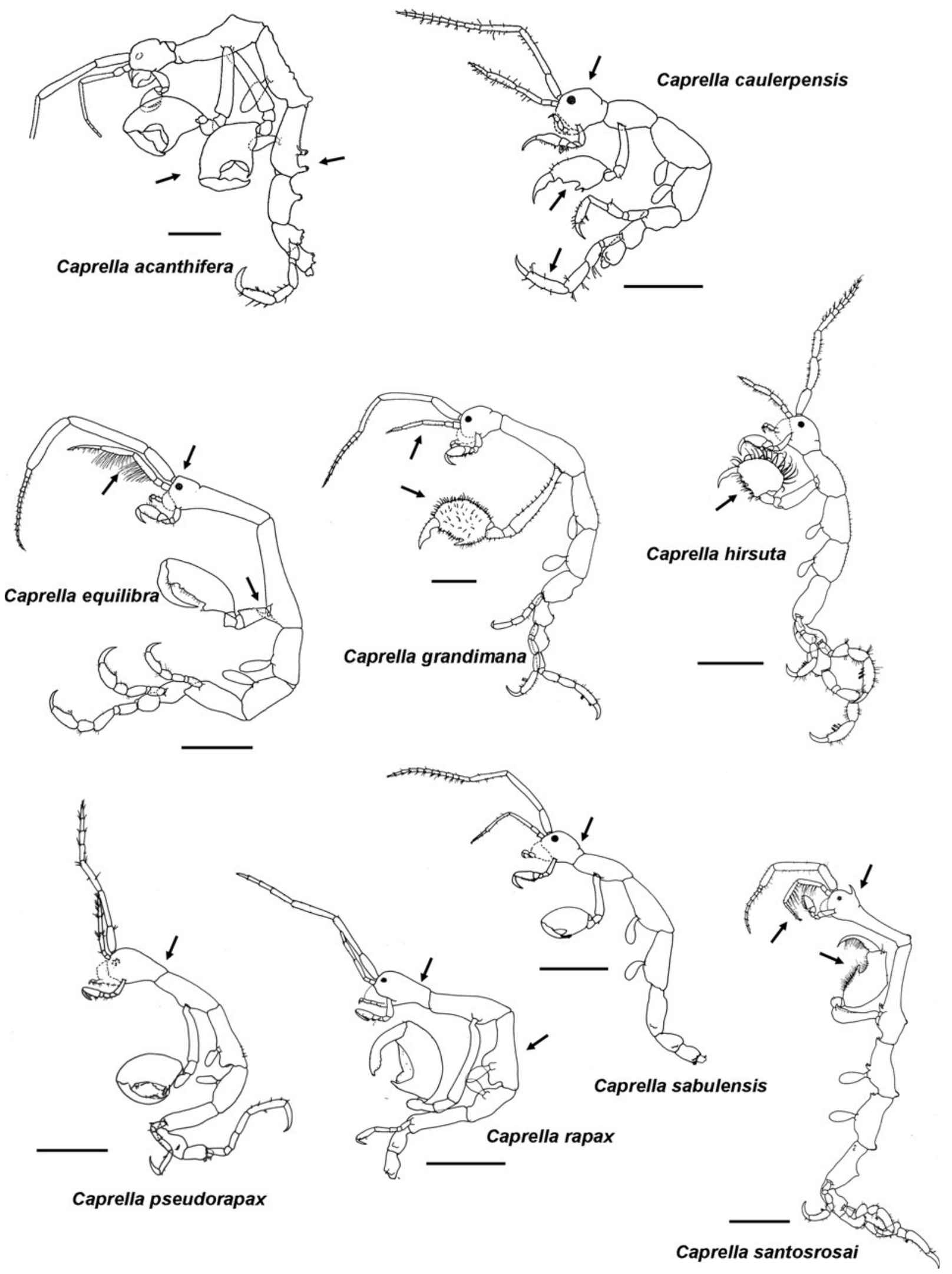

Fig. 2 Male lateral view figures of caprellids inhabiting soft bottoms of the Iberian Peninsula. Refigured from Krapp-Schickel (1993), Laubitz and Sorbe (1996), Guerra-García et al. (2000, 2001a, b, c, 2002b, 2008), Guerra-García and Takeuchi (2002), Riera et al. (2003). Scale bars 1 mm 


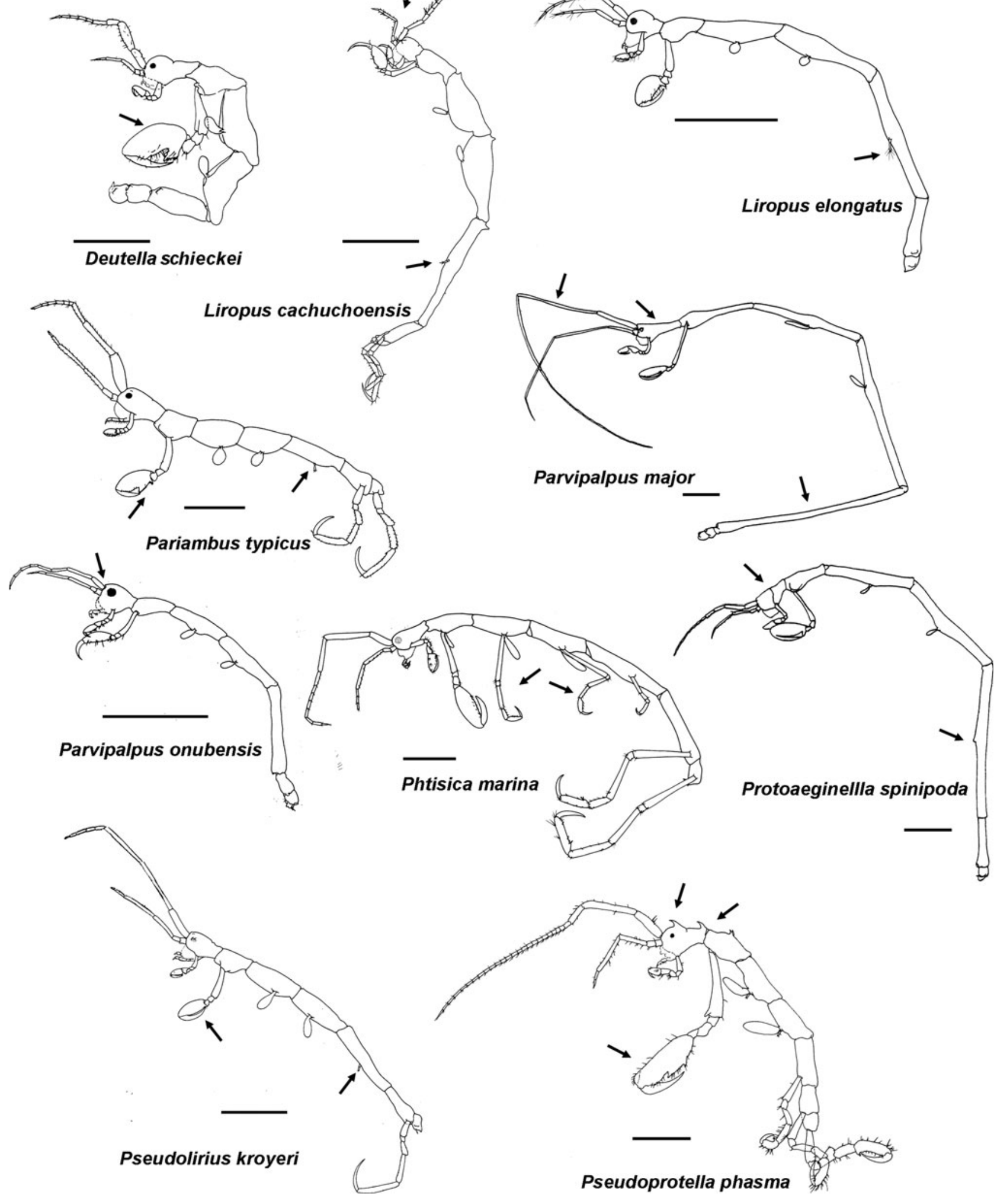

Fig. 2 continued 
Fig. 3 Lateral view of a generalized caprellid (Pseudoprotella phasma) showing the different parts used in the key

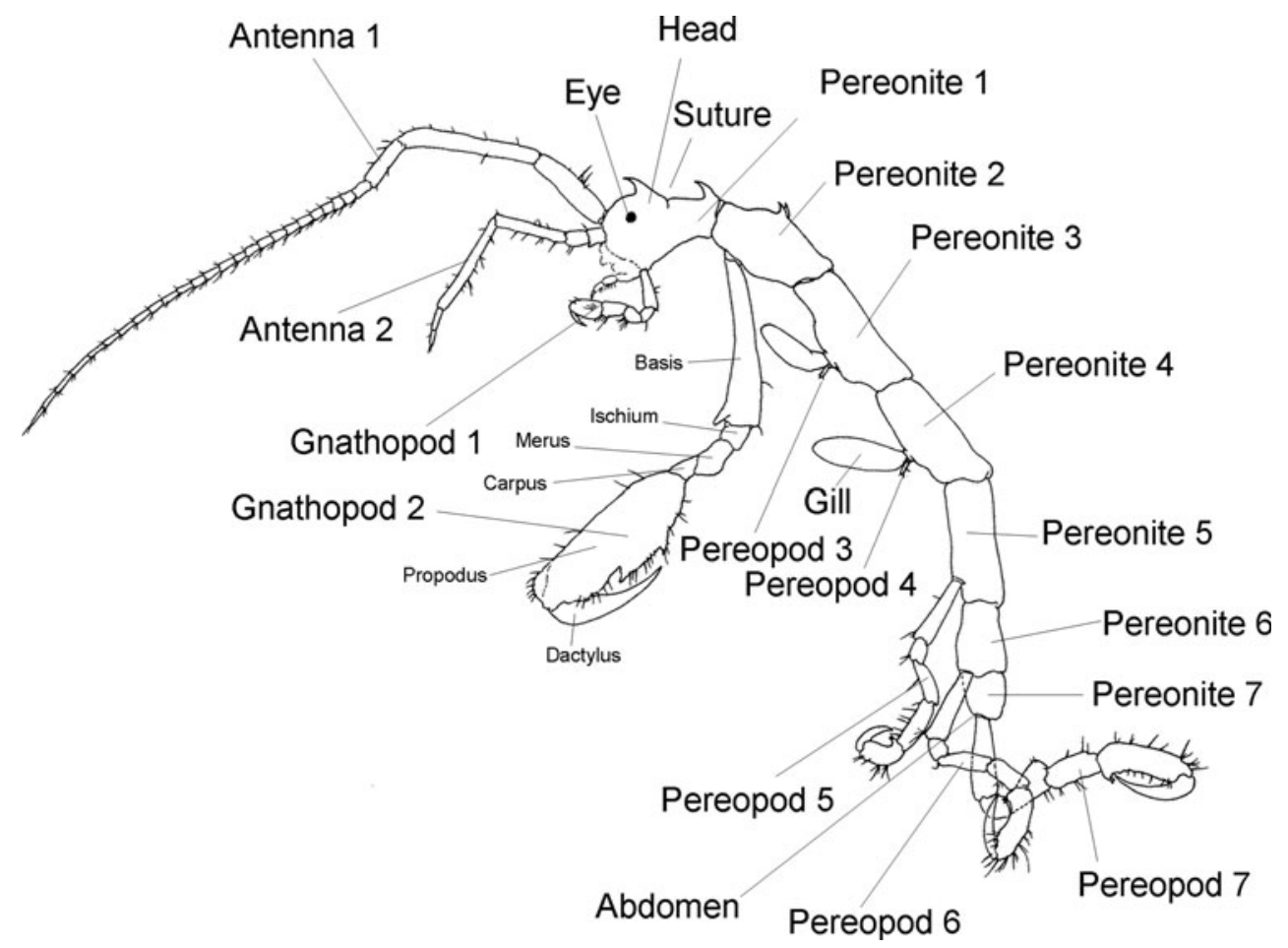

been rarely reported along the Iberian Peninsula's coasts. Marti (1989) cited the species in Valencia Gulf, and Estacio (1996) found the species in sediments of Algeciras Bay, especially in fine sands and mud. The present study reveals that $P$. kroyeri is significantly more abundant than $P$. typicus along the Andalusian coasts. However, after consulting technical reports conducted by universities, public and private companies, $P$. typicus is usually the only species reported and P. kroyeri is rarely cited. Adult males of both species can be clearly distinguished by the gnathopod 2, but subadult males or juveniles have similar gnathopods, and examination of "abdomen" is necessary for a correct identification. Probably, both species have been misidentified in many of these reports, assigning all the specimens to $P$. typicus, and these mistakes could eventually be published as part of checklists, ecological or biogeographical papers. As a result, the abundance of $P$. kroyeri has been underestimated. For all these reasons, taxonomists are encouraged to provide illustrated keys to non-specialists, necessary to undertake correct identifications. Authorities and policy makers should also be aware of the importance of taxonomy as basic tool for properly conducting applied studies.

Phtisica marina and P. typicus are very common in soft bottoms along the Iberian Peninsula, inhabiting gravels, coarse sands, fine sands and muddy sediments (SánchezMata 1996; Lourido et al. 2008; Sánchez-Moyano and García-Asencio 2010). Although the CCA conducted during the present study showed positive correlation of these two species with coarse sands and gravels, the three- way ANOVA did not show significant differences of abundance among substrates. Guerra-García and GarcíaGómez (2006) conducted a recolonization experiment of defaunated sediments and did not find clear differences in the preference patterns of these two species between the trays with coarse sands and fine sands. P. marina was slightly more abundant in coarse sands, while $P$. typicus reached highest densities in coarse sands after 30 days of recolonization but was more abundant in fine sands after 90 days. Although $P$. typicus has been found free-living on the sea floor, it has also been regularly found on asteroids, ophiuroids and echinoids, establishing a complex association of commensalism (Volbehr and Racor 1997).

The three dominant species found in the present study (P. marina, P. typicus and P. kroyeri) are used as bioindicators to evaluate the quality of coastal marine environments (de-la-Ossa-Carretero et al. 2012). Nevertheless, their sensitivity to pollution is not clear, since there is disagreement among the biotic factors used for their classification. $P$. marina is able to inhabit very polluted sediments (Guerra-García and García-Gómez 2004) or cling to seeweeds located in polluted waters (Guerra-García and García-Gómez 2001). According to the BENTIX classification, this species is tolerant to pollutants (Borja et al. 2000) and our data agree with this. However, this same species has been detected to be relatively sensitive to sewage discharges (de-la-Ossa-Carretero et al. 2012) and AMBI classification reported this species as sensitive (Simboura and Zenetos 2002). On the other hand, 


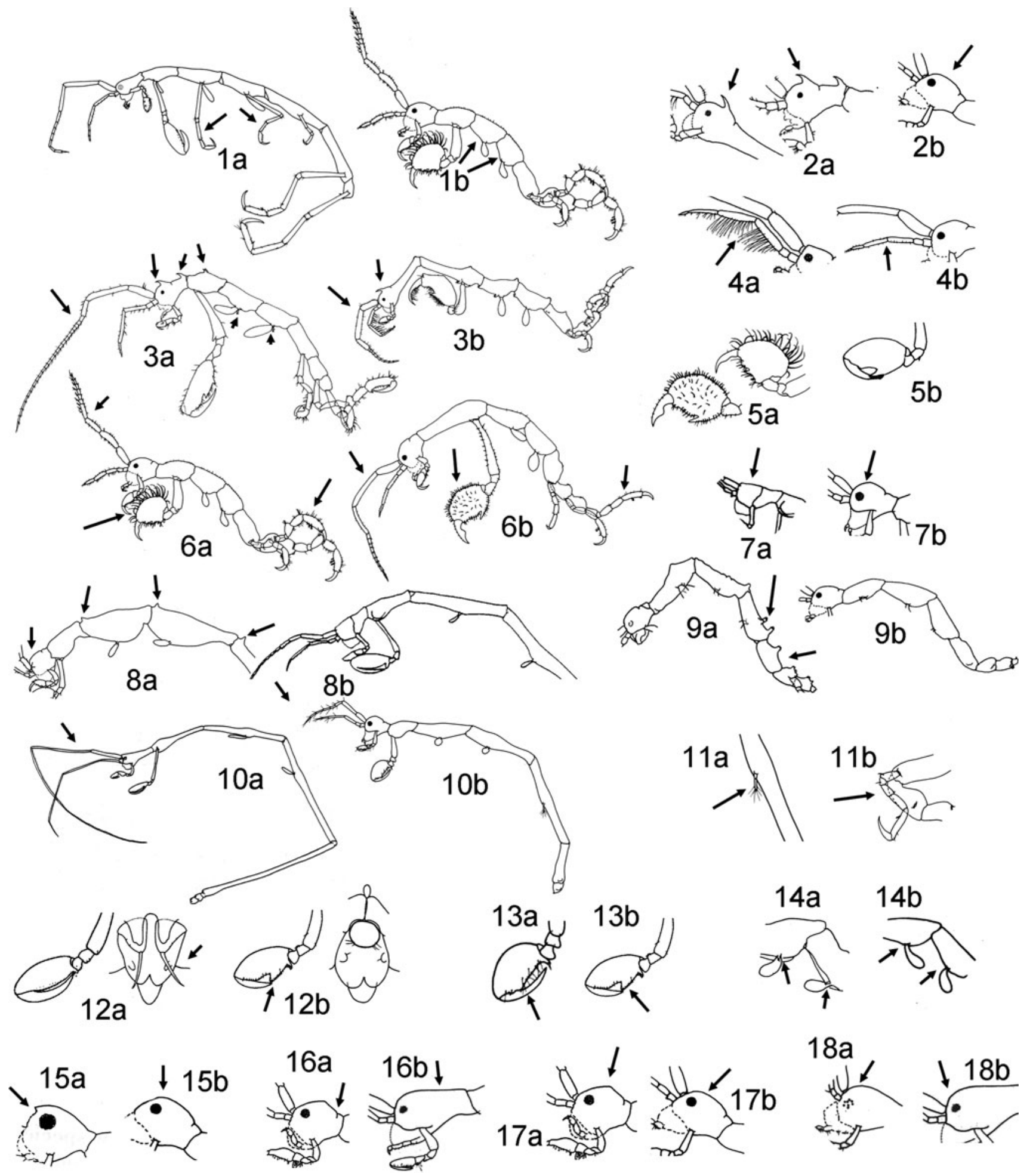

Fig. 4 Details of the main morphological characters to identify the soft-bottom caprellids of the Iberian Peninsula. Numbers (1-18) and letters $(a, b)$ correspond to the options of the taxonomical key provided

P. typicus has been reported as a tolerant species by AMBI and BENTIX lists (Borja et al. 2000; Simboura and Zenetos 2002), although the species also shows sensitivity to the presence of sewage pollution (de-la-Ossa-Carretero et al. 2012). Our study showed higher abundances in sites with low levels of phosphorous in sediments.

Apart from these three dominant species, the remaining caprellids living in sediments are usually found in low 
Table 2 Position, depth, water parameters measured at the water column bottom (chlorophyll $a$, oxygen, salinity, temperature) and sediment parameters ( $P$ total phosphorous, $N$ total nitrogen, $O M$ organic matter, $G$ gravels, $C S$ coarse and very coarse sands, $M S$ medium sands, $F S$ fine and very fine sands, $S C$ silts and clays)

\begin{tabular}{|c|c|c|c|c|c|c|c|c|c|c|c|c|c|c|c|c|c|}
\hline \multirow[t]{2}{*}{ Station } & \multirow[t]{2}{*}{ Coordinates } & \multirow{2}{*}{$\begin{array}{l}\text { Depth } \\
(\mathrm{m})\end{array}$} & \multirow[t]{2}{*}{ Years } & \multirow{2}{*}{$\begin{array}{l}\text { Chla } \\
\left(\mathrm{mg} / \mathrm{m}^{3}\right)\end{array}$} & \multirow{2}{*}{$\begin{array}{l}\text { Oxy. } \\
(\mathrm{mg} / \mathrm{l})\end{array}$} & \multirow{2}{*}{$\begin{array}{l}\text { Salinity } \\
\text { (psu) }\end{array}$} & \multirow{2}{*}{$\begin{array}{l}\text { Temp. } \\
\left({ }^{\circ} \mathrm{C}\right)\end{array}$} & \multirow[t]{2}{*}{$\mathrm{pH}$} & \multirow{2}{*}{$\begin{array}{l}P \\
(\mathrm{mg} / \mathrm{kg})\end{array}$} & \multirow{2}{*}{$\begin{array}{l}N \\
(\mathrm{mg} / \mathrm{kg})\end{array}$} & \multirow{2}{*}{$\begin{array}{l}\mathrm{OM} \\
(\%)\end{array}$} & \multicolumn{5}{|c|}{ Grain size } & \multirow[t]{2}{*}{ Caprellids } \\
\hline & & & & & & & & & & & & $\begin{array}{l}G \\
(\%)\end{array}$ & $\begin{array}{l}\text { CS } \\
(\%)\end{array}$ & $\begin{array}{l}\text { MS } \\
(\%)\end{array}$ & $\begin{array}{l}\text { FS } \\
(\%)\end{array}$ & $\begin{array}{l}\text { SC } \\
(\%)\end{array}$ & \\
\hline 1 & $\begin{array}{l}7^{\circ} 19^{\prime} 25^{\prime \prime} \mathrm{W} \\
37^{\circ} 12^{\prime} 26^{\prime \prime} \mathrm{N}\end{array}$ & 5 & 2009 & 1.79 & 7.1 & 36.85 & 20.0 & 8.11 & 6.7 & 6.5 & 3.8 & 55 & 10 & 2 & 7 & 26 & $\mathrm{Pm}$ \\
\hline 2 & $\begin{array}{l}7^{\circ} 12^{\prime} 01^{\prime \prime} \mathrm{W} \\
36^{\circ} 09^{\prime} 16^{\prime \prime} \mathrm{N}\end{array}$ & 15 & 2009 & 1.22 & 6.9 & 36.40 & 18.3 & 8.02 & 12.8 & 38.0 & 2.1 & 7 & 10 & 19 & 53 & 11 & $\mathrm{Cs}$ \\
\hline \multirow[t]{2}{*}{3} & $\begin{array}{l}7^{\circ} 10^{\prime} 02^{\prime \prime} \mathrm{W} \\
37^{\circ} 13^{\prime} 45^{\prime \prime} \mathrm{N}\end{array}$ & 3 & 2009 & 2.53 & 4.2 & 40.54 & 24.0 & 7.47 & 41.0 & 48.0 & 5.2 & - & - & - & - & - & $\mathrm{Pm}$ \\
\hline & & & 2010 & 2.62 & 4.0 & 40.11 & 26.2 & 7.65 & 43.0 & 8.5 & 2.9 & 1 & 1 & 1 & 45 & 52 & $\mathrm{Pk}$ \\
\hline 4 & $\begin{array}{l}7^{\circ} 00^{\prime} 33^{\prime \prime} \mathrm{W} \\
37^{\circ} 13^{\prime} 08^{\prime \prime} \mathrm{N}\end{array}$ & 3 & 2009 & 4.73 & 4.3 & 37.12 & 23.2 & 7.64 & 316.5 & 86.8 & 6.7 & 22 & 2 & 1 & 7 & 68 & $\mathrm{Pm}$ \\
\hline 5 & $\begin{array}{l}6^{\circ} 58^{\prime} 36^{\prime \prime} \mathrm{W} \\
37^{\circ} 12^{\prime} 35^{\prime \prime} \mathrm{N}\end{array}$ & 7 & 2009 & 2.46 & 5.7 & 37.21 & 23.3 & 7.80 & 64.0 & 38.0 & 3.8 & 1 & 1 & 1 & 18 & 79 & $\mathrm{Pp}, \mathrm{Pm}$ \\
\hline 6 & $\begin{array}{l}6^{\circ} 53^{\prime} 11^{\prime \prime} \mathrm{W} \\
37^{\circ} 09^{\prime} 13^{\prime \prime} \mathrm{N}\end{array}$ & 10 & 2009 & 4.10 & 6.9 & 36.78 & 25.0 & 7.94 & 37.0 & 6.8 & 10.9 & 55 & 1 & 0 & 0 & 44 & $\mathrm{Pm}$ \\
\hline 7 & $\begin{array}{l}6^{\circ} 15^{\prime} 28^{\prime \prime} \mathrm{W}, \\
36^{\circ} 30^{\prime} 44^{\prime \prime} \mathrm{N}\end{array}$ & 7 & 2009 & 3.53 & 6.8 & 37.33 & 25.5 & 8.26 & 24.4 & 125.0 & 9.9 & 1 & 6 & 6 & 46 & 41 & $\mathrm{Pm}$ \\
\hline 8 & $\begin{array}{l}6^{\circ} 13^{\prime} 19^{\prime \prime} \mathrm{W}, \\
36^{\circ} 29^{\prime} 25^{\prime \prime} \mathrm{N}\end{array}$ & 2 & 2009 & 3.13 & 6.8 & 37.47 & 25.7 & 8.26 & 20.4 & 129.0 & 10.1 & - & - & - & - & - & $\mathrm{Pm}$ \\
\hline 9 & $\begin{array}{l}5^{\circ} 58^{\prime} 19^{\prime \prime} \mathrm{W} \\
36^{\circ} 09^{\prime} 03^{\prime \prime} \mathrm{N}\end{array}$ & 25 & 2009 & 0.59 & 7.4 & 36.82 & 20.9 & 8.30 & 15.0 & 10.0 & 1.3 & 12 & 77 & 4 & 5 & 2 & $\mathrm{Cr}, \mathrm{Pp}$ \\
\hline 10 & $\begin{array}{l}5^{\circ} 41^{\prime} 42^{\prime \prime} \mathrm{W} \\
\quad 36^{\circ} 02^{\prime} 42^{\prime \prime} \mathrm{N}\end{array}$ & 25 & 2009 & 1.25 & 7.4 & 36.91 & 18.7 & 7.54 & 11.4 & 63.0 & 1.3 & 1 & 2 & 2 & 92 & 3 & $\mathrm{Pt}$ \\
\hline 11 & $\begin{array}{l}5^{\circ} 33^{\prime} 05^{\prime \prime} \mathrm{W} \\
\quad 36^{\circ} 01^{\prime} 05^{\prime \prime} \mathrm{N}\end{array}$ & 25 & 2009 & 0.72 & 8.0 & 37.58 & 16.5 & 8.25 & 7.4 & 75.0 & 4.4 & 42 & 40 & 4 & 12 & 2 & $\mathrm{Pt}, \mathrm{Pk}, \mathrm{Pm}, \mathrm{Cs}$ \\
\hline 12 & $\begin{array}{l}5^{\circ} 28^{\prime} 28^{\prime \prime} \mathrm{W} \\
36^{\circ} 02^{\prime} 49^{\prime \prime} \mathrm{N}\end{array}$ & 15 & 2010 & 0.79 & 6.9 & 37.00 & 19.2 & 8.20 & 14.5 & 100.0 & 2.4 & 2 & 47 & 36 & 14 & 1 & $\mathrm{Pt}$ \\
\hline 13 & $\begin{array}{l}5^{\circ} 25^{\prime} 53^{\prime \prime} \mathrm{W} \\
36^{\circ} 08^{\prime} 31^{\prime \prime} \mathrm{N}\end{array}$ & 15 & 2010 & 2.40 & 6.9 & 36.87 & 20.9 & 8.19 & 19.7 & 6.8 & 2.1 & 1 & 1 & 2 & 38 & 58 & $\mathrm{Pk}$ \\
\hline \multirow[t]{2}{*}{14} & $\begin{array}{l}5^{\circ} 25^{\prime} 46^{\prime \prime} \mathrm{W} \\
36^{\circ} 09^{\prime} 35^{\prime \prime} \mathrm{N}\end{array}$ & 25 & 2009 & 0.72 & 8.1 & 37.34 & 18.1 & 8.22 & 13.1 & 49.0 & 0.9 & 4 & 2 & 1 & 87 & 6 & $\mathrm{Pk}$ \\
\hline & & & 2010 & 2.20 & 6.9 & 36.89 & 20.4 & 8.19 & 10.7 & 9.1 & 0.9 & 1 & 2 & 3 & 80 & 14 & $\mathrm{Pk}, \mathrm{Pm}$ \\
\hline 15 & $\begin{array}{l}5^{\circ} 25^{\prime} 32^{\prime \prime} \mathrm{W} \\
36^{\circ} 10^{\prime} 15^{\prime \prime} \mathrm{N}\end{array}$ & 25 & 2010 & 0.81 & 7.4 & 37.40 & 15.5 & 8.10 & 13.9 & 61.0 & 2.7 & 0 & 1 & 2 & 63 & 34 & $\mathrm{Pk}, \mathrm{Pm}$ \\
\hline \multirow[t]{2}{*}{16} & $\begin{array}{l}5^{\circ} 25^{\prime} 27^{\prime \prime} \mathrm{W} \\
36^{\circ} 05^{\prime} 42^{\prime \prime} \mathrm{N}\end{array}$ & 15 & 2009 & 0.81 & 7.8 & 37.48 & 18.3 & 8.19 & 12.6 & 57.0 & 1.7 & 5 & 2 & 3 & 89 & 1 & $\mathrm{Pk}$ \\
\hline & & & 2010 & 1.20 & 7.1 & 36.91 & 20.1 & 8.20 & 19.2 & 124.0 & 2.0 & 1 & 2 & 5 & 88 & 4 & $\mathrm{Pk}$ \\
\hline 17 & $\begin{array}{l}5^{\circ} 24^{\prime} 32^{\prime \prime} \mathrm{W} \\
36^{\circ} 10^{\prime} 38^{\prime \prime} \mathrm{N}\end{array}$ & 25 & 2010 & 0.23 & 6.9 & 37.60 & 14.7 & 8.08 & 28.0 & 89.0 & 5.8 & 12 & 15 & 4 & 23 & 46 & $\mathrm{Pk}$ \\
\hline 18 & $\begin{array}{l}5^{\circ} 23^{\prime} 23^{\prime \prime} \mathrm{W} \\
36^{\circ} 10^{\prime} 38^{\prime \prime} \mathrm{N}\end{array}$ & 36 & 2009 & 0.85 & 7.1 & 38.36 & 14.2 & 8.19 & 14.3 & 46.0 & 2.0 & 11 & 0 & 2 & 42 & 45 & $\mathrm{Pk}$ \\
\hline \multirow[t]{2}{*}{19} & $\begin{array}{l}5^{\circ} 22^{\prime} 39^{\prime \prime} \mathrm{W} \\
36^{\circ} 09^{\prime} 66^{\prime \prime} \mathrm{N}\end{array}$ & 10 & 2009 & 0.72 & 8.0 & 37.58 & 16.5 & 8.25 & 7.4 & 75.0 & 0.9 & 1 & 2 & 6 & 86 & 5 & $\mathrm{Pk}, \mathrm{Pt}, \mathrm{Pm}$ \\
\hline & & & 2010 & 0.75 & 7.2 & 36.88 & 20.0 & 8.22 & 11.7 & 9.6 & 2.4 & 0 & 1 & 4 & 87 & 8 & $\mathrm{Pk}$ \\
\hline 20 & $\begin{array}{l}5^{\circ} 21^{\prime} 33^{\prime \prime} \mathrm{W} \\
36^{\circ} 09^{\prime} 30^{\prime \prime} \mathrm{N}\end{array}$ & 4 & 2010 & 0.98 & 7.1 & 36.82 & 21.6 & 8.21 & 9.5 & 229.0 & 6.0 & 9 & 18 & 9 & 23 & 41 & $\mathrm{Pk}$ \\
\hline \multirow[t]{2}{*}{21} & $\begin{array}{l}5^{\circ} 18^{\prime} 48^{\prime \prime} \mathrm{W} \\
\quad 36^{\circ} 12^{\prime} 02^{\prime \prime} \mathrm{N}\end{array}$ & 12 & 2009 & 1.57 & 7.5 & 37.52 & 17.0 & 8.14 & 9.8 & 45.0 & 0.9 & 1 & 3 & 2 & 92 & 2 & $\mathrm{Pk}, \mathrm{Pm}$ \\
\hline & & & 2010 & 0.49 & 7.0 & 37.47 & 21.8 & 8.25 & 14.0 & 27.8 & 1.2 & 1 & 1 & 1 & 93 & 4 & $\mathrm{Pk}$ \\
\hline \multirow[t]{2}{*}{22} & $\begin{array}{l}5^{\circ} 08^{\prime} 23^{\prime \prime} \mathrm{W} \\
36^{\circ} 24^{\prime} 49^{\prime \prime} \mathrm{N}\end{array}$ & 15 & 2009 & 0.97 & 7.7 & 37.37 & 17.4 & 8.11 & 12.1 & 49.0 & 4.1 & 1 & 1 & 0 & 82 & 16 & $\mathrm{Pk}$ \\
\hline & & & 2010 & 0.52 & 6.9 & 37.49 & 22.9 & 8.23 & 12.2 & 16.4 & 1.1 & 1 & 1 & 1 & 86 & 11 & $\mathrm{Pk}$ \\
\hline \multirow[t]{2}{*}{23} & $\begin{array}{l}4^{\circ} 52^{\prime} 33^{\prime \prime} \mathrm{W} \\
36^{\circ} 29^{\prime} 55^{\prime \prime} \mathrm{N}\end{array}$ & 15 & 2007 & 0.55 & 7.8 & 37.38 & 16.2 & - & 9.6 & - & - & 13 & 47 & 7 & 26 & 7 & $\mathrm{Pm}$ \\
\hline & & & 2010 & 0.45 & 7.0 & 37.41 & 23.3 & 8.26 & 19.6 & 2.1 & 0.9 & 4 & 7 & 4 & 51 & 34 & $\mathrm{Pk}, \mathrm{Pm}$ \\
\hline \multirow[t]{2}{*}{24} & $\begin{array}{l}4^{\circ} 36^{\prime} 31^{\prime \prime} \mathrm{W}, \\
36^{\circ} 32^{\prime} 41^{\prime \prime} \mathrm{N}\end{array}$ & 15 & 2009 & 0.36 & 7.2 & 37.60 & 21.3 & 8.14 & 13.2 & 12.4 & 1.6 & 1 & 3 & 5 & 83 & 8 & $\mathrm{Pk}$ \\
\hline & & & 2010 & - & 7.0 & 37.44 & 17.6 & 8.37 & 16.0 & 68.0 & 1.4 & 0 & 4 & 5 & 83 & 8 & $\mathrm{Pk}, \mathrm{Pm}$ \\
\hline 25 & $\begin{array}{l}4^{\circ} 26^{\prime} 21^{\prime \prime} \mathrm{W}, \\
36^{\circ} 39^{\prime} 441^{\prime \prime} \mathrm{N}\end{array}$ & 15 & 2007 & 0.72 & 8.0 & 36.82 & 18.9 & 8.40 & 11.3 & 39.4 & 2.0 & 0 & 0 & 0 & 36 & 64 & $\mathrm{Pk}$ \\
\hline
\end{tabular}


Table 2 continued

\begin{tabular}{|c|c|c|c|c|c|c|c|c|c|c|c|c|c|c|c|c|c|}
\hline \multirow[t]{2}{*}{ Station } & \multirow[t]{2}{*}{ Coordinates } & \multirow{2}{*}{$\begin{array}{l}\text { Depth } \\
(\mathrm{m})\end{array}$} & \multirow[t]{2}{*}{ Years } & \multirow{2}{*}{$\begin{array}{l}\text { Chla } \\
\left(\mathrm{mg} / \mathrm{m}^{3}\right)\end{array}$} & \multirow{2}{*}{$\begin{array}{l}\text { Oxy. } \\
(\mathrm{mg} / \mathrm{l})\end{array}$} & \multirow{2}{*}{$\begin{array}{l}\text { Salinity } \\
\text { (psu) }\end{array}$} & \multirow{2}{*}{$\begin{array}{l}\text { Temp. } \\
\left({ }^{\circ} \mathrm{C}\right)\end{array}$} & \multirow[t]{2}{*}{$\mathrm{pH}$} & \multirow{2}{*}{$\begin{array}{l}P \\
(\mathrm{mg} / \mathrm{kg})\end{array}$} & \multirow{2}{*}{$\begin{array}{l}N \\
(\mathrm{mg} / \mathrm{kg})\end{array}$} & \multirow{2}{*}{$\begin{array}{l}\mathrm{OM} \\
(\%)\end{array}$} & \multicolumn{5}{|c|}{ Grain size } & \multirow[t]{2}{*}{ Caprellids } \\
\hline & & & & & & & & & & & & $\begin{array}{l}G \\
(\%)\end{array}$ & $\begin{array}{l}\text { CS } \\
(\%)\end{array}$ & $\begin{array}{l}\text { MS } \\
(\%)\end{array}$ & $\begin{array}{l}\text { FS } \\
(\%)\end{array}$ & $\begin{array}{l}\mathrm{SC} \\
(\%)\end{array}$ & \\
\hline 26 & $\begin{array}{l}4^{\circ} 24^{\prime} 58^{\prime \prime} \mathrm{W} \\
36^{\circ} 42^{\prime} 24^{\prime \prime} \mathrm{N}\end{array}$ & 15 & 2009 & 0.31 & 7.1 & 37.66 & 22.1 & 8.18 & 5.1 & 34.2 & 1.6 & 0 & 1 & 0 & 14 & 85 & $\mathrm{Pk} . \mathrm{Pt}$ \\
\hline \multirow[t]{2}{*}{27} & $\begin{array}{l}4^{\circ} 22^{\prime} 04^{\prime \prime} \mathrm{W} \\
36^{\circ} 42^{\prime} 45^{\prime \prime} \mathrm{N}\end{array}$ & 35 & 2009 & 0.36 & 6.7 & 35.31 & 21.1 & 8.15 & 10.4 & 65.0 & 2.3 & 0 & 1 & 1 & 65 & 33 & $\mathrm{Pk}, \mathrm{Pt}, \mathrm{Pm}$ \\
\hline & & & 2010 & 0.19 & 6.8 & 37.52 & 22.7 & 8.29 & 18.0 & 5.4 & 2.9 & 0 & 0 & 0 & 43 & 57 & $\mathrm{Pk}$ \\
\hline 28 & $\begin{array}{l}4^{\circ} 11^{\prime} 48^{\prime \prime} \mathrm{W} \\
36^{\circ} 42^{\prime} 10^{\prime \prime} \mathrm{N}\end{array}$ & 15 & 2007 & - & 7.4 & 36.40 & 16.7 & 8.20 & 9.3 & 26.3 & 1.2 & 1 & 8 & 34 & 55 & 2 & $\mathrm{Pk}$ \\
\hline 29 & $\begin{array}{l}3^{\circ} 51^{\prime} 44^{\prime \prime} \mathrm{W} \\
36^{\circ} 44^{\prime} 47^{\prime \prime} \mathrm{N}\end{array}$ & 25 & 2010 & 0.13 & 5.7 & 37.14 & 14.5 & 8.19 & 11.2 & 19.9 & 0.9 & 1 & 1 & 1 & 66 & 31 & $\mathrm{Pk}, \mathrm{Pm}$ \\
\hline \multirow[t]{3}{*}{30} & $\begin{array}{l}3^{\circ} 46^{\prime} 38^{\prime \prime} \mathrm{W} \\
36^{\circ} 44^{\prime} 02^{\prime \prime} \mathrm{N}\end{array}$ & 25 & 2007 & 0.29 & 7.7 & 36.72 & 20.9 & 8.40 & 18.1 & 39.2 & 1.7 & 9 & 6 & 7 & 68 & 10 & $\mathrm{Pk}$ \\
\hline & & & 2009 & 0.10 & 6.5 & 38.13 & 26.7 & 8.17 & 10.8 & 20.2 & 0.9 & 5 & 54 & 6 & 30 & 5 & $\mathrm{Pm}, \mathrm{Ca}$ \\
\hline & & & 2010 & 0.22 & 6.8 & 37.59 & 23.6 & 8.23 & 6.6 & 13.7 & 0.9 & 13 & 71 & 2 & 8 & 6 & $\mathrm{Pk}, \mathrm{Pt}$ \\
\hline \multirow[t]{3}{*}{31} & $\begin{array}{l}3^{\circ} 41^{\prime} 16^{\prime \prime} \mathrm{W}, \\
36^{\circ} 43^{\prime} 35^{\prime \prime} \mathrm{N}\end{array}$ & 25 & 2007 & 0.18 & 7.4 & 36.82 & 15.4 & 7.85 & 12.7 & 1.3 & 1.6 & 3 & 5 & 4 & 41 & 47 & $\mathrm{Pk}$ \\
\hline & & & 2009 & 0.10 & 6.5 & 38.12 & 25.9 & 8.16 & 10.7 & 5.8 & 5.1 & 5 & 55 & 5 & 30 & 5 & $\mathrm{Pk}$ \\
\hline & & & 2010 & 0.16 & 6.6 & 37.12 & 15.7 & 8.01 & 8.6 & 5.9 & 2.7 & 13 & 71 & 2 & 8 & 6 & $\mathrm{Pk}$ \\
\hline \multirow[t]{2}{*}{32} & $\begin{array}{l}3^{\circ} 32^{\prime} 00^{\prime \prime} \mathrm{W}, \\
36^{\circ} 43^{\prime} 06^{\prime \prime} \mathrm{N}\end{array}$ & 15 & 2009 & 0.10 & 6.7 & 38.09 & 25.8 & 8.20 & 10.7 & 24.6 & 2.2 & 0 & 0 & 0 & 34 & 66 & $\mathrm{Pk}$ \\
\hline & & & 2010 & 0.14 & 6.3 & 37.52 & 25.3 & 8.28 & 16.1 & 11.5 & 3.0 & 2 & 0 & 0 & 50 & 48 & $\mathrm{Pk}$ \\
\hline \multirow[t]{3}{*}{33} & $\begin{array}{l}3^{\circ} 10^{\prime} 23^{\prime \prime} \mathrm{W} \\
36^{\circ} 44^{\prime} 39^{\prime \prime} \mathrm{N}\end{array}$ & 25 & 2007 & 0.22 & 7.6 & 37.04 & 16.9 & 7.86 & 7.1 & 14.9 & 0.9 & 0 & 1 & 6 & 88 & 5 & $\mathrm{Pk}$ \\
\hline & & & 2009 & 0.10 & 6.4 & 38.06 & 21.7 & 8.29 & 10.7 & 50.0 & 2.3 & 1 & 8 & 3 & 59 & 29 & $\mathrm{Pk}, \mathrm{Pm}$ \\
\hline & & & 2010 & 0.15 & 6.4 & 37.61 & 24.1 & 8.25 & 3.9 & 4.3 & 2.7 & 14 & 77 & 1 & 4 & 4 & $\mathrm{Pk}, \mathrm{Pm}$ \\
\hline \multirow[t]{2}{*}{34} & $\begin{array}{l}2^{\circ} 27^{\prime} 48^{\prime \prime} \mathrm{W} \\
36^{\circ} 49^{\prime} 46^{\prime \prime} \mathrm{N}\end{array}$ & 10 & 2009 & 1.33 & 6.4 & 38.05 & 26.7 & 8.22 & 13.6 & 17.3 & 4.4 & 1 & 3 & 1 & 30 & 65 & $\mathrm{Pk}$ \\
\hline & & & 2010 & 0.54 & 7.0 & 36.98 & 22.7 & 8.07 & 17.9 & 6.2 & 2.2 & 0 & 1 & 1 & 19 & 79 & $\mathrm{Pk}, \mathrm{Pm}$ \\
\hline \multirow[t]{3}{*}{35} & $\begin{array}{l}2^{\circ} 26^{\prime} 55^{\prime \prime} \mathrm{W} \\
\quad 36^{\circ} 48^{\prime} 28^{\prime \prime} \mathrm{N}\end{array}$ & 15 & 2007 & 0.73 & 6.6 & 36.65 & 21.0 & 8.13 & 9.2 & 19.70 & 0.9 & 3 & 7 & 5 & 81 & 4 & $\mathrm{Pm}$ \\
\hline & & & 2009 & 0.10 & 6.5 & 38.04 & 26.2 & 8.24 & 4.5 & 11.0 & 0.9 & 1 & 4 & 5 & 87 & 3 & $\mathrm{Pt}$ \\
\hline & & & 2010 & 0.15 & 7.2 & 36.97 & 23.5 & 8.11 & 22.9 & 19.6 & 1.7 & 20 & 47 & 7 & 14 & 12 & $\mathrm{Pm}$ \\
\hline \multirow[t]{3}{*}{36} & $\begin{array}{l}2^{\circ} 14^{\prime} 47^{\prime \prime} \mathrm{W}, \\
36^{\circ} 46^{\prime} 06^{\prime \prime} \mathrm{N}\end{array}$ & 25 & 2007 & 0.48 & 6.6 & 36.72 & 21.5 & 8.15 & 7.4 & 25.3 & 1.1 & 1 & 4 & 50 & 44 & 1 & $\mathrm{Pm}$ \\
\hline & & & 2009 & 0.10 & 6.5 & 38.05 & 25.8 & 8.20 & 3.0 & 2.6 & 1.0 & 0 & 0 & 0 & 97 & 3 & $\mathrm{Pk}$ \\
\hline & & & 2010 & 0.15 & 6.5 & 37.21 & 25.3 & 8.09 & 8.8 & 15.3 & 1.4 & 0 & 0 & 1 & 95 & 4 & $\mathrm{Pt}, \mathrm{Pm}$ \\
\hline 37 & $\begin{array}{l}2^{\circ} 05^{\prime} 26^{\prime \prime} \mathrm{W} \\
36^{\circ} 45^{\prime} 14^{\prime \prime} \mathrm{N}\end{array}$ & 35 & 2009 & 0.10 & 7.1 & 37.55 & 19.6 & 8.16 & 10.6 & 39.0 & 1.5 & 0 & 1 & 0 & 78 & 21 & $\mathrm{Pm}$ \\
\hline 38 & $\begin{array}{l}1^{\circ} 53^{\prime} 28^{\prime \prime} \mathrm{W} \\
36^{\circ} 59^{\prime} 07^{\prime \prime} \mathrm{N}\end{array}$ & 15 & 2010 & 0.10 & 6.6 & 37.27 & 25.8 & 8.08 & 4.4 & 3.2 & 0.9 & 0 & 14 & 15 & 65 & 6 & $\mathrm{Pt}$ \\
\hline 39 & $\begin{array}{l}1^{\circ} 48^{\prime} 13^{\prime \prime} \mathrm{W} \\
37^{\circ} 11^{\prime} 04^{\prime \prime} \mathrm{N}\end{array}$ & 29 & 2010 & 0.22 & 8.0 & 37.81 & 18.5 & 8.05 & 5.3 & 4.2 & 0.9 & 0 & 0 & 0 & 89 & 11 & $\mathrm{Pt}$ \\
\hline 40 & $\begin{array}{l}1^{\circ} 40^{\prime} 55^{\prime \prime} \mathrm{W} \\
37^{\circ} 19^{\prime} 11^{\prime \prime} \mathrm{N}\end{array}$ & 25 & 2009 & 0.10 & - & 37.74 & 19.8 & 8.19 & 6.8 & 4.3 & - & 2 & 6 & 3 & 79 & 10 & $\mathrm{Ca}, \mathrm{Pm}$ \\
\hline
\end{tabular}

Caprellids found in each station are also included

Ca Caprella acanthifera; Cr Caprella rapax; Cs Caprella sabulensis; Pk Pseudolirius kroyeri; Pm Phtisica marina; Pp Pseudoprotella phasma; Pt Pariambus typicus

abundances, have narrow distribution areas or are poorly known due to the lack of ecological and biogeographical studies. Many of these species have very small sizes and are often overlooked during sorting, especially if the samples are not stained with Bengal rose, so further studies are necessary to properly characterise the ecological and geographical distribution of these species.

\section{Caprellid diversity of the Iberian Peninsula}

The caprellid fauna of the Iberian Peninsula (considering both soft and hard bottoms) consists of 35 species (Table 5). This number of species is high when compared with other Mediterranean and North Atlantic regions (Atlantic coast of USA and Canada: 30 species; North 


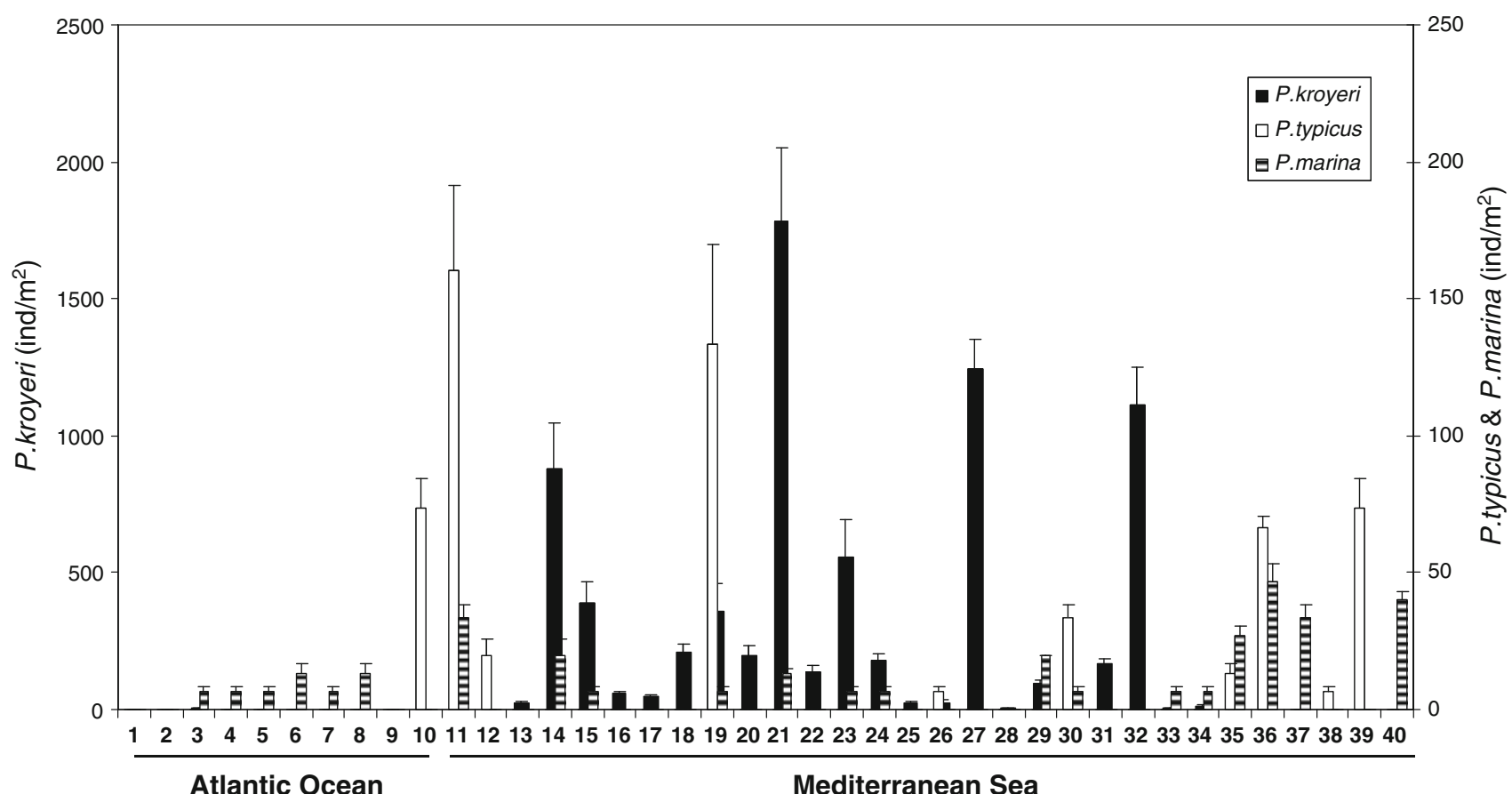

Fig. 5 Abundance $\left(\mathrm{ind} / \mathrm{m}^{2}\right.$ ) of the three dominant caprellids species along the Andalusian coast

Fig. 6 Graphic representation of the stations, years, species and variables with respect to the first two axes of the canonical correspondence analysis (CCA). Oxy oxygen, $P$ total phosphorous, $G$ gravels, $C S$ coarse and very coarse sands, $M S$ medium sands, $S C$ silts and clays
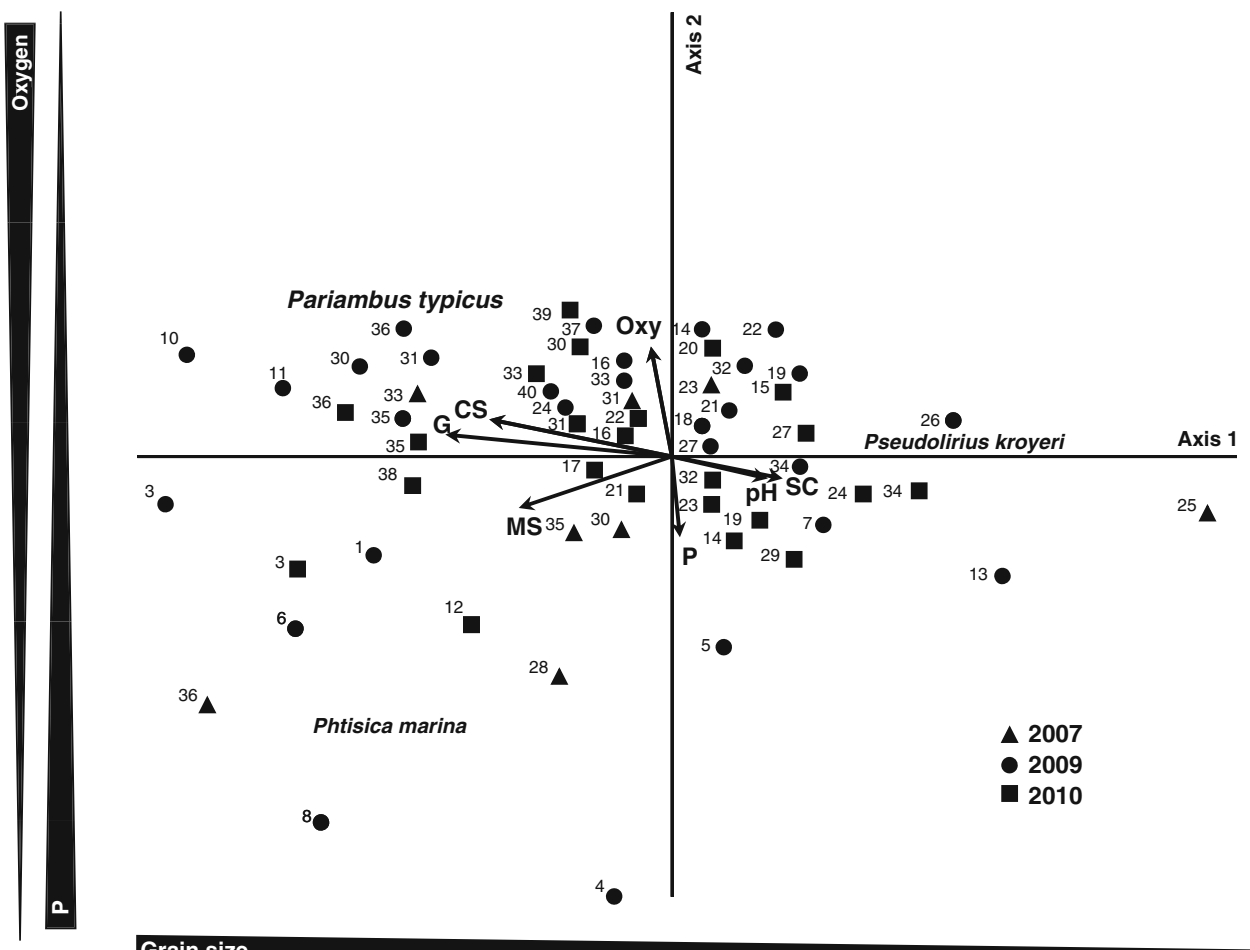

Grain size
Atlantic (from $55^{\circ} \mathrm{N}$ ): 33 species; British Isles: 13 species; Black Sea: 7 species; whole Mediterranean Sea: 41 species) (Guerra-García and Takeuchi 2002; Sturaro and Guerra-García 2012). In fact, if we examine the list of species for the Mediterranean Sea (see Sturaro and GuerraGarcía 2012), there are only 6 species (out of the 41 cited) that are not recorded so far in the Iberian Peninsula: Caprella lilliput Krapp-Schickel and Ruffo, 1987, C. 
Table 3 Summary of the results of the CCA analysis

\begin{tabular}{lcll}
\hline & Axis 1 & Axis 2 & Axis 3 \\
\hline Eigenvalue & 0.37 & 0.13 & 0.01 \\
Species-environment correlation & 0.72 & 0.46 & 0.11 \\
Percentage of species variance & 28.40 & 9.90 & 0.01 \\
Correlation with environmental & & & \\
$\quad$ variables & & & \\
Oxygen (mg/l) & - & $0.26^{*}$ & - \\
pH & $0.27^{*}$ & - & $0.27 *$ \\
$P$ (mg/kg) & - & $0.24^{*}$ & - \\
$G$ (gravels) (\%) & $-0.41^{* * *}$ & - & $0.39^{* *}$ \\
CS (coarse sands) (\%) & $-0.29^{*}$ & - & $-0.29 *$ \\
MS (medium sands) (\%) & $-0.33^{* *}$ & - & - \\
SC (silt and clay) $(\%)$ & $0.25^{*}$ & - & $0.27 *$ \\
\hline
\end{tabular}

Only the variables that correlated with the first three axes were included

* $P<0.05$; ** $P<0.01$; *** $P<0.001$ tavolarensis Sturaro and Guerra-García, 2012, C. telarpax Mayer, 1890, Liropus minimus Mayer, 1890, Parvipalpus linea Mayer, 1890 and Pedoculina bacescui A. Carausu, 1940. The Iberian Peninsula is of great interest from a zoogeographical point of view, receiving direct influence of Mediterranean and Atlantic Ocean, and being the boundary for the Mediterranean region (to the east), the Lusitanian region (to the north-east) and the Mauritanian region (to the south-east).

Of the 35 species recorded so far at the Iberian Peninsula, 19 species $(54 \%)$ have been collected from soft bottoms, indicating the importance of these ecosystems to host caprellids. For example, a recent survey of caprellids associated with macroalgae from intertidal and shallow waters $(0-5 \mathrm{~m})$ of the whole Iberian Peninsula (including 250 samples of 46 algal species) showed the presence of only 11 species (Guerra-García et al. 2010b). The softbottom caprellid fauna from the Iberian Peninsula has an important Mediterranean endemism component, with $42 \%$

Table 4 Results of the ANOVA (three-factor) for abundance of the dominant caprellid species

\begin{tabular}{|c|c|c|c|c|c|c|c|c|c|c|c|}
\hline \multirow[t]{2}{*}{ Source of variation } & \multirow[t]{2}{*}{$d f$} & \multicolumn{3}{|c|}{ P. kroyeri } & \multicolumn{3}{|c|}{ P. marina } & \multicolumn{3}{|c|}{ P. typicus } & \multirow[t]{2}{*}{$F$ versus } \\
\hline & & MS & $F$ & $P$ & MS & $F$ & $P$ & MS & $F$ & $P$ & \\
\hline Depth (De) & 1 & 4.45 & 1.23 & 0.2989 & 0.44 & 0.15 & 0.7078 & 0.02 & 0.01 & 0.9792 & $\mathrm{Si}(\mathrm{De} \times \mathrm{Se})$ \\
\hline Sediment type (Se) & 1 & 45.24 & 12.54 & $0.0076 * *$ & 2.77 & 0.94 & 0.3599 & 96.69 & 2.52 & 0.1510 & $\mathrm{Si}(\mathrm{De} \times \mathrm{Se})$ \\
\hline Site $(\mathrm{De} \times \mathrm{Se})$ & 8 & 3.60 & 5.28 & $0.0007 * * *$ & 2.94 & 1.38 & 0.2563 & 38.36 & 2.06 & 0.0817 & Res \\
\hline $\mathrm{De} \times \mathrm{Se}$ & 1 & 0.01 & 0.01 & 0.9821 & 0.44 & 0.15 & 0.7078 & 0.02 & 0.01 & 0.9792 & $\mathrm{Si}(\mathrm{De} \times \mathrm{Se})$ \\
\hline Residual & 24 & \multicolumn{3}{|l|}{0.68} & \multicolumn{3}{|l|}{2.14} & \multicolumn{3}{|l|}{18.61} & \\
\hline Cochran's $C$ test & & \multicolumn{3}{|c|}{$C=0.3127$} & \multicolumn{3}{|c|}{$C=0.7403(P<0.01)$} & \multicolumn{3}{|c|}{$C=0.5552(P<0.01)$} & \\
\hline Transformation & & \multicolumn{3}{|c|}{$\ln (X+1)$} & \multicolumn{3}{|c|}{ None } & \multicolumn{3}{|l|}{ None } & \\
\hline
\end{tabular}

$M S$ mean square, $P$ level of probability, $d f$ degree of freedom

** $P<0.01 ; * * * P<0.001$
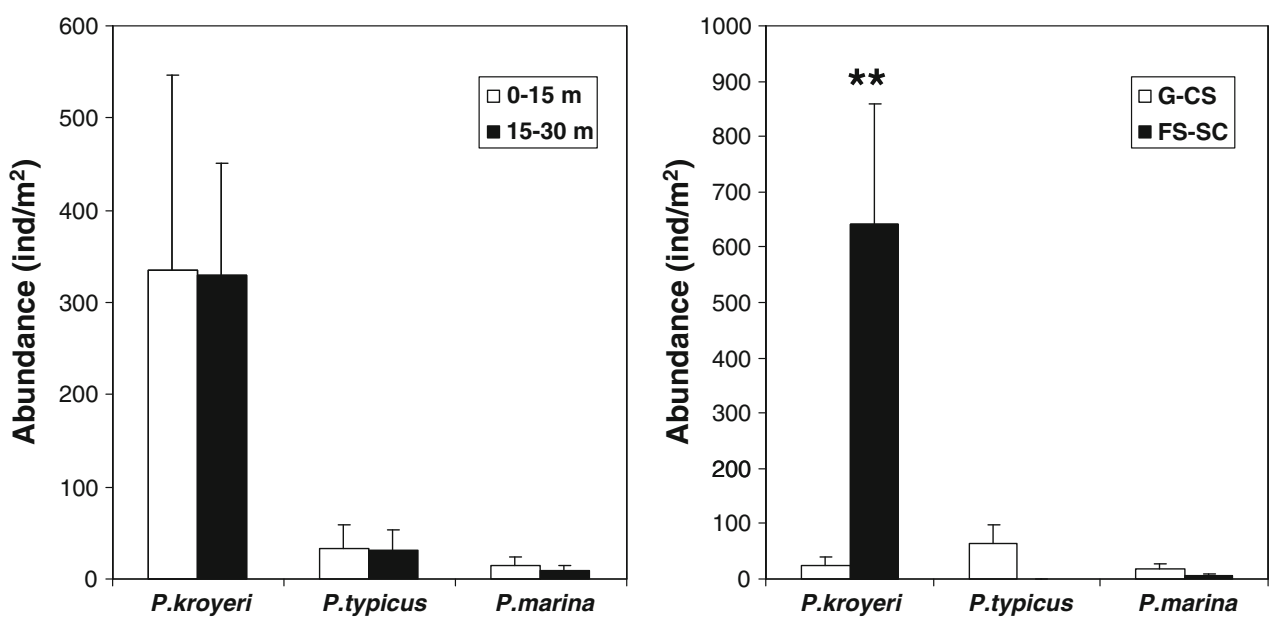

Fig. 7 Abundances (ind $/ \mathrm{m}^{2}$ ) (mean value $\pm \mathrm{SE}$ ) of the three dominant caprellids according to the depth (0-15 $\mathrm{m}$ vs. 15-30 m) and sediment type (gross vs. fine sediments). $G$ gravels, $C S$ coarse and very coarse sands, $F S$ fine and very fine sands, $S C$ silts and clays 
Table 5 Caprellids recorded from soft and hard bottoms at the Iberian Peninsula

\begin{tabular}{|c|c|}
\hline Name of species & Distribution \\
\hline Caprella acanthifera Leach, 1814 & $\mathrm{M}, \mathrm{A}$ \\
\hline Caprella andreae Mayer, 1890 & $\mathrm{M}, \mathrm{A}, \mathrm{P}$ \\
\hline Caprella caulerpensis Guerra-García, Sánchez-Moyano and García-Gomez, 2002 & E \\
\hline Caprella danilevskii Czerniavski, 1868 & $\mathrm{M}, \mathrm{A}, \mathrm{P}, \mathrm{I}$ \\
\hline Caprella dilatata Krøyer, 1843 & $\mathrm{M}, \mathrm{A}$ \\
\hline Caprella equilibra Say, 1818 & $\mathrm{M}, \mathrm{A}, \mathrm{P}, \mathrm{I}$ \\
\hline Caprella erethizon Mayer, 1901 & $\mathrm{M}, \mathrm{A}$ \\
\hline Caprella fretensis Stebbing, 1878 & $\mathrm{M}, \mathrm{A}$ \\
\hline Caprella grandimana Mayer, 1882 & $\mathrm{E}$ \\
\hline Caprella hirsuta Mayer, 1890 & $\mathrm{E}$ \\
\hline Caprella linearis (Linnaeus, 1767) & A \\
\hline Caprella liparotensis Haller, 1879 & $\mathrm{M}, \mathrm{A}$ \\
\hline Caprella mitis Mayer, 1890 & $\mathrm{E}$ \\
\hline Caprella paramitis Guerra-García, Sánchez-Moyano and García-Gómez, 2001 & $\mathrm{E}$ \\
\hline Caprella penantis Leach, 1840 & $\mathrm{M}, \mathrm{A}, \mathrm{P}, \mathrm{I}$ \\
\hline Caprella pseudorapax Guerra-García, Sánchez-Moyano and García-Gómez, 2001 & E \\
\hline Caprella rapax Mayer, 1890 & M, A \\
\hline Caprella sabulensis Guerra-García, Sánchez-Moyano and García-Gómez, 2001 & M, A \\
\hline Caprella santosrosai Sánchez-Moyano, Jiménez-Martín and García-Gómez, 1995 & $\mathrm{E}$ \\
\hline Caprella scaura Templeton, 1836 & $\mathrm{M}, \mathrm{A}, \mathrm{P}, \mathrm{I}$ \\
\hline Caprella takeuchii Guerra-García, Sánchez-Moyano and García-Gómez, 2001 & E \\
\hline Caprella tuberculata Bate and Westwood, 1868 & M, A \\
\hline Caprella sp (armata-group) (see Krapp-Schickel and Vader 1998) & M, A \\
\hline Deutella schieckei Cavedini, 1982 & $\mathrm{E}$ \\
\hline Liropus cachuchoensis Guerra-García, Sorbe and Frutos, 2008 & A \\
\hline Liropus elongatus Mayer, 1890 & $\mathrm{E}$ \\
\hline Pariambus typicus Krøyer, 1844 & $\mathrm{M}, \mathrm{A}$ \\
\hline Parvipalpus major A. Carausu, 1941 & $\mathrm{M}, \mathrm{A}$ \\
\hline Parvipalpus onubensis Guerra-García, García-Asencio and Sánchez-Moyano, 2001 & A \\
\hline Pedoculina garciagomezi Sánchez-Moyano et al. 1995 & E \\
\hline Phtisica marina Slabber, 1769 & $\mathrm{M}, \mathrm{A}, \mathrm{P}$ \\
\hline Protoaeginella spinipoda Laubitz and Sorbe, 1996 & A \\
\hline Pseudolirius kroyerii (Haller, 1879) & E \\
\hline Pseudoprotella inermis Chevreux, 1927 & M, A \\
\hline Pseudoprotella phasma (Montagu, 1804) & $\mathrm{M}, \mathrm{A}$ \\
\hline
\end{tabular}

References: Mayer (1882, 1890), Cavedini (1981), Marques and Bellan-Santini (1985), Krapp-Schickel (1993), Jimeno and Turón (1995), Sánchez-Moyano et al. (1995), Laubitz and Sorbe (1996), Bellan-Santini and Ruffo (1998), Krapp-Schickel and Vader (1998), Estacio (1996), Guerra-García and Takeuchi (2000), Guerra-García (2001, 2004), Guerra-García et al. (2000, 2001a, b, c, d, 2002b, 2008, 2010b, 2011), Bachelet et al. (2003), González et al. (2008), Lourido et al. (2008), Moreira et al. (2008), Vázquez-Luis et al. (2009), Cacabelos et al. (2010), de-la-OssaCarretero et al. (2010), Sánchez-Moyano and García-Asencio (2010, 2011)

$E$ Mediterranean endemic, $M$ Mediterranean Sea, $A$ Atlantic Ocean, $P$ Pacific Ocean, $I$ Indian Ocean

of species being endemic to the Mediterranean (Table 1). This percentage is very similar to the percentage of caprellids' endemism in the Mediterranean (40\%) (Guerra-García and Takeuchi 2002; Sturaro and GuerraGarcía 2012) and only a little higher than the $37 \%$ reported by Bellan-Santini and Ruffo (1998) for Mediterranean caprellids and gammarids combined. These values are higher than the $26.6 \%$ calculated by Fredj et al. (1992) for all of the Mediterranean fauna taken together. Only three species (16\%), Liropus cachuchoensis, Parvipalpus onubensis and Protoaeginella spinipoda, are restricted so far to the Atlantic coast, being absent from the Mediterranean basin.

Only within the last 20 years, the $37 \%$ of the species inhabiting sediments have been described (Table 1), 
indicating that soft bottoms had been scarcely explored in comparison with other ecosystems. However, most of the environmental monitoring programmes (urban and industrial outfalls, oil spills and other impacts) are usually focused on sediment communities and technical reports usually include lists of soft-bottom taxa together with the abiotic data. Consequently, identifying amphipods inhabiting sediments should be considered as a relevant tool, especially now that the WFD is focused on the environmental control of the littoral zone and giving priority to amphipods for this task. Unfortunately, there is a general lack of taxonomical tools for species identification, and non-specialists usually have problems to successfully identify their specimens. For the case of caprellids, identifications are more difficult when only females or juveniles are available, since most of the important characters for identification can be observed only in adult males. Furthermore, sediment samples are usually sieved after collecting, and caprellids easily loose the pereopods 5-7 during sieving (see Fig. 2) making identifications even more difficult. Often, similar species can be misidentified in technical reports or even in ecological papers that are eventually published. Additional efforts should be conducted to explore caprellid diversity in soft bottoms, especially biodetritics and sediments from deep sea, which have been scarcely explored. Undoubtedly, many new records and species will be found in these areas.

Acknowledgments We are very grateful to two anonymous referees for their constructive comments and suggestions. Special thanks to G. Rivera-Ingraham for the English revision of the manuscript. Support of this work was provided by the Ministerio de Educación y Ciencia (Proyect CGL2011-22474) co-financed by FEDER funds, and by the Consejería de Innovación, Ciencia y Empresa, Junta de Andalucía (Projects P07-RNM-02524 y P11-RNM-7041).

\section{References}

Bachelet G, Dauvin JC, Sorbe JC (2003) Updated checklist of marine and brackish water Amphipoda (Crustacea: Peracarida) of the southern Bay of Biscay (NE Atlantic). Cah Biol Mar 44:121-151

Bellan-Santini D, Ruffo S (1998) Faunistics and zoogeograpy. In: Ruffo S (ed) The Amphipoda of the Mediterranean, vol 13. Mémoires de l'Institut Oceanographique, Monaco, pp 895-911

Borja A, Franco J, Perez V (2000) A marine biotic index to establish the ecological quality of soft-bottom benthos within European estuarine and coastal environments. Mar Pollut Bull 40:1100-1114

Buchanan JD, Kain JM (1984) Measurement of the physical and chemical environment. In: Holme HL, McIntre AD (eds) Methods for the study of marine benthos. Blackwell, Oxford, pp 30-50

Cacabelos E, Lourido A, Troncoso JS (2010) Composition and distribution of subtidal and intertidal crustacean assemblages in soft-bottoms of the Ria de Vigo (NW Spain). Sci Mar 74:455-464

Caine EA (1974) Comparative functional morphology of feeding in three species of caprellids (Crustacea, Amphipoda) from the northwestern Florida gulf coast. J Exp Mar Biol Ecol 15:81-96
Caine EA (1987) Potential effect of floating dock communities on a South Carolina estuary. J Exp Mar Biol Ecol 108:83-91

Caine EA (1989) Caprellid amphipod behaviour and predatory strikes by fish. J Exp Mar Biol Ecol 126:173-180

Caine EA (1991) Caprellid amphipods: fast food for the reproductively active. J Exp Mar Biol Ecol 148:27-33

Cavedini P (1981) Contributo alla conoscenza dei Caprellidi del Mediterraneo. Boll Mus Civ St Nat Verona 8:493-531

Clarke KR, Gorley RN (2001) PRIMER (Plymouth Routines In Multivariate Ecological Research) v5: user manual/tutorial. PRIMER-E Ltd, Plymouth

de-la-Ossa-Carretero JA, Dauvin JC, Del-Pilar-Ruso Y, JiménezCasalduero F, Sánchez-Lizaso JL (2010) Inventory of benthic amphipods from fine sand community of the Iberian Peninsula east coast (Spain), western Mediterranean, with new records. Mar Biol Rec 3 e119:1-10

de-la-Ossa-Carretero JA, Del-Pilar-Ruso Y, Giménez-Casalduero F, Sánchez-Lisazo JL, Dauvin JC (2012) Sensitivity of amphipods to sewage pollution. Estuar Coast Shelf Sci 96:129-138

Estacio FJ (1996) Distribución y variación espacio-temporal de las comunidades macrobentónicas del sedimento en la Bahía de Algeciras. Implicaciones en la evaluación de la calidad ambiental del medio marino. Tesis Doctoral, Universidad de Sevilla, p 482

Fredj G, Bellan-Santini D, Meinardi M (1992) État des connaissances sur la faune marine méditerranéenne. Bull de L'Inst Océanogr, Monaco 9:133-145

González AR, Guerra-García JM, Maestre MJ, Ruiz-Tabares A, Espinosa F, Gordillo I, Sánchez-Moyano JE, García-Gómez JC (2008) Community structure of caprellids (Crustacea: Amphipoda: Caprellidae) on seagrasses from southern Spain. Helgol Mar Res 62:189-199

Guerra-García JM (2001) Habitat use of the Caprellidea (Crustacea: Amphipoda) from Ceuta, North Africa. Ophelia 55:27-38

Guerra-García JM (2004) Deep-sea Caprellidea (Crustacea, Amphipoda) from Azores with the description of three new species. Zoosystema 26:235-262

Guerra-García JM, García-Gómez JC (2001) The spatial distribution of Caprellidea (Crustacea: Amphipoda): a stress bioindicator in Ceuta (North Africa, Gibraltar area). PSZNI Mar Ecol 22: 357-367

Guerra-García JM, García-Gómez JC (2004) Crustacean assemblages and sediment pollution in an exceptional case study: a harbour with two opposing entrances. Crustaceana 77:353-370

Guerra-García JM, García-Gómez JC (2006) Recolonization of defaunated sediments: fine versus gross sand and dredging versus experimental trays. Est Coast Shelf Sci 68:328-342

Guerra-García JM, Izquierdo D (2010) Caprellids (Crustacea: Amphipoda) associated with the intertidal alga Corallina elongata along the Iberian Peninsula. Mar Biol Rec 3 e42:1-7

Guerra-García JM, Koonjul MS (2005) Metaprotella sandalensis (Crustacea: Amphipoda: Caprellidae): a bioindicator of nutrient enrichment on coral reefs? A preliminary study at Mauritius Island. Environ Monit Assess 104:353-367

Guerra-García JM, Takeuchi I (2000) Redescription of Pseudoprotella inermis Chevreux, 1927, a rare species of caprellidean amphipod (Crustacea) from Ceuta, North Africa. Proc Biol Soc Wash 113:980-988

Guerra-García JM, Takeuchi I (2002) The Caprelllidea (Crustacea: Amphipoda) from Ceuta, North Africa, with the description of three species of Caprella, a key to the species of Caprella, and biogeographical discussion. J Nat Hist 36:675-713

Guerra-García JM, Tierno de Figueroa JM (2009) What do the caprellids feed on? Mar Biol 156:1881-1890

Guerra-García JM, Sánchez-Moyano JE, García-Gómez JC (2000) Redescription of Caprella hirsuta Mayer, 1890 (Crustacea, 
Amphipoda, Caprellidea) from the Strait of Gibraltar. Miscel Zool 23:69-78

Guerra-García JM, Sánchez-Moyano JE, García-Gómez JC (2001a) Two new species of Caprella (Crustacea: Amphipoda: Caprellidea) collected from sandy bottoms in the Strait of Gibraltar. Hidrobiologia 448:181-192

Guerra-García JM, Sánchez-Moyano JE, García-Gómez JC (2001b) Two new hairy species of Caprella (Crustacea: Amphipoda) from the Strait of Gibraltar, with the redescription of Caprella grandimana. J Crust Biol 21:1014-1030

Guerra-García JM, García-Asencio I, Sánchez-Moyano JE (2001c) Parvipalpus onubensis, a new species (Crustacea: Amphipoda: Caprellidea) from the Atlantic coast of Southern Spain. Sci Mar 65:333-339

Guerra-García JM, Sánchez-Moyano JE, García-Gómez JC (2001d) A new species of Caprella (Amphipoda, Caprellidea) from Algeciras Bay, Southern Spain. Crustaceana 74:211-219

Guerra-García JM, Corzo J, García-Gómez JC (2002a) Clinging behaviour of the Caprellidea (Amphipoda) from the Strait of Gibraltar. Crustaceana 75:41-50

Guerra-García JM, Sánchez-Moyano JE, García-Gómez JC (2002b) Caprella caulerpensis (Crustacea: Amphipoda), a new species of caprellid associated to Caulerpa prolifera (Forsskal) Lamouroux from the Strait of Gibraltar. J Mar Biol Assoc UK 82:843-846

Guerra-García JM, Sorbe JC, Frutos I (2008) A new species of Liropus (Crustacea, Amphipoda, Caprellidae) from Le Danois bank (southern Bay of Biscay). Org Div Evol 7:253e1-253e12

Guerra-García JM, Sánchez JA, Ros M (2009) Distributional and ecological patterns of caprellids (Crustacea: Amphipoda) associated with the seaweed Stypocaulon scoparium in the Iberian Peninsula. Mar Bio Rec 2 e151:1-8

Guerra-García JM, Ruiz-Tabares A, Baeza-Rojano E, Cabezas MP, Díaz-Pavón JJ, Pacios I, Maestre M, González AR, Espinosa F, García-Gómez JC (2010a) Trace metals in Caprella (Crustacea: Amphipoda). A new tool for monitoring pollution in coastal areas? Ecol Indicat 10:734-743

Guerra-García JM, Ros M, Gordillo I, Cabezas MP, Baeza-Rojano E, Izquierdo D, Corzo J, Domínguez J, Varona S (2010b) Distribution patterns of intertidal and shallow water caprellids associated with macroalgae along the Iberian Peninsula. Zool Baet 21:101-129

Guerra-García JM, Ros M, Dugo-Cota A, Burgos V, Flores-León AM, Baeza-Rojano E, Cabezas P, Núñez J (2011) Geographical expansion of the invader Caprella scaura (Crustacea: Amphipoda: Caprellidae) to the East Atlantic coast. Mar Biol 158: 2617-2622

Jimeno A, Turón X (1995) Gammaridea and Caprellidea of the northeast coast of Spain: ecological distribution on different types of substrata. Polsk Arch Hydrobiol 42:495-516

Krapp-Schickel T (1993) Suborder Caprellidea. In: Ruffo S (ed) The Amphipoda of the Mediterranean, vol 13. Mémoires de l'Institut Oceanographique, Monaco, pp 773-809

Krapp-Schickel T, Vader W (1998) What is, and what is not, Caprella acanthifera Leach, 1814 (Amphipoda, Caprellidea)? Part 1: the acanthifera-group. J Nat Hist 32:949-967

Laubitz DR, Sorbe JC (1996) Deep-water caprellids (Amphipoda: Caprellidea) from the Bay of Biscay: a new species and a new locality record. J Crust Biol 16:626-632

Lourido A, Moreira J, Troncoso JS (2008) Assemblages of peracarid crustaceans in subtidal sediments from the Ría de Aldán (Galicia, NW Spain). Helgol Mar Res 62:289-301

Marques JC, Bellan-Santini D (1985) Contribution à l'étude systématique et écologique des amphipods (Crustacea-Amphipoda) des côtes du Portugal. Premier inventaire des espèces (Gammaridens et Caprelliens). Ciênc Biol Ecol Syst 5:299-353
Marti A (1989) Anfípodos del litoral de Alborada-Albuixech (Golfo de Valencia, Mediterráneo Occidental). Estudio faunístico y ecológico. Tesis de licenciatura, Universitat de Valencia

Mayer P (1882) Die Caprelliden des Golfes von Neapel und der angrenzenden Meeres-Abschnitte. Fauna und Flora des Golfes von Neapel 6:1-201

Mayer P (1890) Die Caprelliden des Golfes von Neapel und der angrenzenden Meeres-Abschnitte. Fauna Flora Golf. Neapel 17:1-55

Mayer P (1903) Die Caprelliden der Siboga-Expedition. Siboga Expeditie 34:1-160

McCain JC (1968) The Caprellidea (Crustacea: Amphipoda) of the Western North Atlantic. Bull US Natl Museum 278:1-116

Moreira J, Lourido A, Troncoso JS (2008) Diversity and distribution of peracarid crustaceans in shallow subtidal soft bottoms at the Ensenada de Baiona (Galicia, NW Spain). Crustaceana 81:1069_ 1089

Ohji M, Takeuchi I, Takahashi S, Tanabe S, Miyazaki N (2002) Differences in the acute toxicities of tributyltin between the Caprellidea and the Gammaridea (Crustacea: Amphipoda). Mar Pollut Bull 44:16-24

Riera R, Guerra-García JM, Brito MC, Núñez J (2003) Estudio de los caprélidos de Lanzarote, Islas Canarias (Crustacea: Amphipoda: Caprellidea). Vieraea 31:157-166

Sánchez-Mata A (1996) El macrozoobentos submareal de la Ría de Ares y Betanzos. Tesis Doctoral, Universidad de Santiago de Compostela, p 628

Sánchez-Moyano JE, García-Asencio I (2010) Crustacean assemblages in a polluted estuary from South-Western Spain. Mar Pollut Bull 60:1890-1897

Sánchez-Moyano JE, García-Asencio I (2011) Crustacean assemblages along the Guadiana River estuary (south-western Iberian Peninsula). J Mar Biol Assoc UK 91:127-138

Sánchez-Moyano JE, Carballo JL, Estacio FJ (1995) Pedoculina garciagomezi (Amphipoda, Caprellidea), new species from Bahía de Algeciras (Southern Spain). Crustaceana 68:418-427

Simboura N, Zenetos A (2002) Benthic indicators to use in ecological quality classification of Mediterranean soft-bottoms marine ecosystems, including a new biotic index. Medit Mar Sci 3/2:77-111

Sturaro N, Guerra-García JM (2012) A new species of Caprella (Crustacea: Amphipoda) from the Mediterranean Sea. Helgol Mar Res 66:33-42

Takeuchi I, Takahashi S, Tanabe S, Miyazaki N (2004) Butylin concentrations along the Japanese coast from 1997 to 1999 monitored by Caprella spp. (Crustacea: Amphipoda). Mar Environ Res 57:397-414

Thiel M, Guerra-García JM, Lancellotti DA, Vásquez N (2003) The distribution of littoral caprellids (Crustacea: Amphipoda: Caprellidea) along the Pacific coast of continental Chile. Rev Chil Hist Nat 76:297-312

Underwood AJ (1997) Experiments in ecology: their logical design and interpretation using analysis of variance. Cambridge University Press, Cambridge, p 504

Underwood AJ, Chapman MG, Richards SA (2002) GMAV-5 for windows. An analysis of variance programme. Centre for Research on Ecological Impacts of Coastal Cities, Marine Ecology Laboratories, University of Sydney, Australia

Vázquez-Luis M, Guerra-García JM, Sánchez-Jerez P, Bayle-Sempere JT (2009) Caprellid assemblages (Crustacea: Amphipoda) in shallow waters invaded by Caulerpa racemosa var. cylindracea from southeastern Spain. Helgol Mar Res 63:107-117

Volbehr U, Racor E (1997) The association between the caprellid Pariambus typicus Krøyer (Crustacea, Amphipoda) and ophiuroids. Hydrobiologia 355:71-76 